San Jose State University

SJSU ScholarWorks

Master's Theses

Master's Theses and Graduate Research

1999

\title{
Bird and arthropod predation of codling moth (Cydia pomonella) in apple orchards
}

Jo Ann Baumgartner

San Jose State University

Follow this and additional works at: https://scholarworks.sjsu.edu/etd_theses

\section{Recommended Citation}

Baumgartner, Jo Ann, "Bird and arthropod predation of codling moth (Cydia pomonella) in apple orchards" (1999). Master's Theses. 1793.

DOI: https://doi.org/10.31979/etd.r6bj-cns5

https://scholarworks.sjsu.edu/etd_theses/1793

This Thesis is brought to you for free and open access by the Master's Theses and Graduate Research at SJSU ScholarWorks. It has been accepted for inclusion in Master's Theses by an authorized administrator of SJSU ScholarWorks. For more information, please contact scholarworks@sjsu.edu. 


\section{INFORMATION TO USERS}

This manuscript has been reproduced from the microfilm master. UMI films the text directly from the original or copy submitted. Thus, some thesis and dissertation copies are in typewriter face, while others may be from any type of computer printer.

The quality of this reproduction is dependent upon the quality of the copy submitted. Broken or indistinct print, colored or poor quality illustrations and photographs, print bleedthrough, substandard margins, and improper alignment can adversely affect reproduction.

In the unlikely event that the author did not send UMI a complete manuscript and there are missing pages, these will be noted. Also, if unauthorized copyright material had to be removed, a note will indicate the deletion.

Oversize materials (e.g., maps, drawings, charts) are reproduced by sectioning the original, beginning at the upper left-hand corner and continuing from left to right in equal sections with small overlaps. Each original is also photographed in one exposure and is included in reduced form at the back of the book.

Photographs included in the original manuscript have been reproduced xerographically in this copy. Higher quality 6" $\mathrm{x} 9$ " black and white photographic prints are available for any photographs or illustrations appearing in this copy for an additional charge. Contact UMI directly to order.

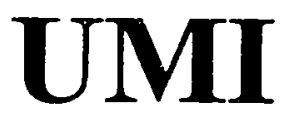

A Bell \& Howell Information Company 300 North Zeeb Road, Ann Arbor MI 48106-1346 USA 

BIRD AND ARTHROPOD PREDATION OF CODLING MOTH (CYDIA POMONELLA)

IN APPLE ORCHARDS

\author{
A Thesis \\ Presented to \\ The Faculty of the Department of Environmental Studies \\ San Jose State University \\ In Partial Fulfillment \\ of the Requirements for the Degree \\ Masters of Science
}

by

Jo Ann Baumgartner

May 1999 
UMI Number: 1394505

Copyright 1999 by Baumgartner, Jo Ann

All rights reserved.

UMI Microform 1394505

Copyright 1999, by UMI Company. All rights reserved.

This microform edition is protected against unauthorized copying under Title 17, United States Code.

\section{UMI}

300 North Zeeb Road

Ann Arbor, MI 48103 
(C) 1999

Jo Ann Baumgartner

\section{ALL RIGHTS RESERVED}


APPROVED FOR THE DEPARTMENT OF ENVIRONMENTAL STUDIES

Mypice Trutir

Dr. Lynne Trulio, Associate Professor of Environmental Studies, Committee Chairperson

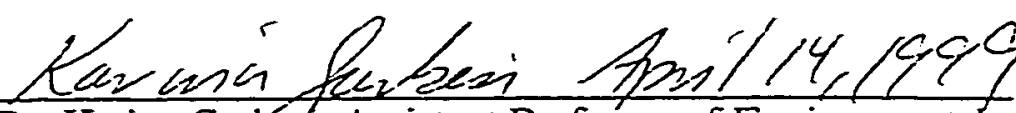

Dr. Karina Garbesti, Assistant Professor of Environmental Studies

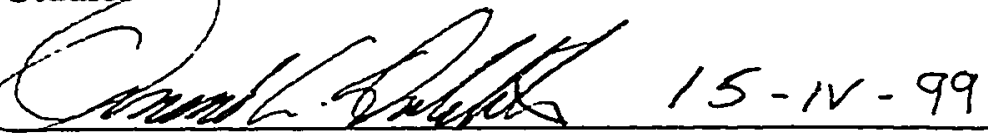

Dr. Don Dahlsten, Associate Dean of College of Natural Resources, \& Professor of Environmental Science, Policy and Management, University of California, Berkeley

APPROVED FOR THE UNIVERSITY

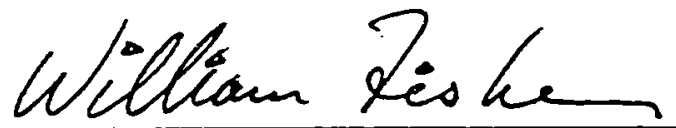




\begin{abstract}
BIRD AND ARTHROPOD PREDATION OF CODLING MOTH (CYDIA POMONELLA) IN APPLE ORCHARDS
\end{abstract}

by Jo Ann Baumgartner

Predation of wintering codling moth Cydia pomonella (L.) larvae by birds and arthropods was examined in Central Califomia Coast apple orchards over a two-year period. Birds impacted codling moth populations during the long cool season diapausing period before the insects emerged as adults.

Trials were conducted at three orchards, all adjacent to native habitat. Larvae were placed directly onto tree bark in year one, and on apple logs placed in trees in year two. Diapausing larvae were exposed to predators and compared with caged larvae where predators were excluded. Predation was higher where birds were present, with an average of $84 \%$ bird predation in year two orchards (chi-square: $\mathrm{p}<0.001$ ). Comparisons of bird survey data showed more species diversity and abundance in abandoned than in managed orchards (Kruskal-Wallis: $\mathrm{p}<0.05$ ), and habitat appeared to influence occurrence of bird species, many of which are known to consume codling moth. 


\section{ACKNOWLEDGMENTS}

I was reading Rachel Carson's Silent Spring at the time I was looking for a thesis topic that would tie birds and agriculture together, and lo and behold, Rachel had cited MacLellan who had reported woodpeckers attacking codling moth. So, it seems fitting to give credit to Rachel Carson for this thesis topic and for awakening the public's awareness of agricultural pesticides and their adverse effects on birds.

Special thanks are due to my husband Sam Earnshaw, who provided encouragement and assistance in the orchards. Thanks are due to to Robert Bugg for giving inspiration and helping me get the big picture.

I'm indebted to my committee members Lynne Trulio, Don Dahlsten, and Karina Garbesi: Lynne for her guidance throughout the project; Don for imparting to me some of his understanding of bird predation of arthropods; and Karina for her analytical mind and her willingness to read my thesis on her Hawaiian vacation.

To Lou Dixon and Nick Mills' lab for generously sending me codling moth larvae - many thanks. I am indebted to Bill Denevan for providing two of the experimental organic orchard sites and for giving his knowledgeable support of my project. Bill's distaste for codling moth was motivating in itself. And thanks to Kim Welch for providing the abandoned orchard.

Finally, I want to thank Organic Farming Research Foundation (OFRP) and University of Califormia Sustainable Agriculture Research and Education Program (UC SAREP) for providing generous financial support. 


\section{TABLE OF CONTENTS}

LIST OF TABLES $\ldots \ldots \ldots \ldots \ldots \ldots \ldots \ldots \ldots \ldots \ldots \ldots \ldots$ viii

LIST OF ILLUSTRATIONS. . . . . . . . .

Chapter

1. INTRODUCTION. . . . . . . . . . . . .

Purpose of the Study .................. 1

Background .................... 5

Bird predation $\ldots \ldots \ldots \ldots \ldots \ldots \ldots \ldots \ldots$

Arthropod parasitism and predation ........... 8

Pathogenic micro-organisms . . . . . . . . . . 9

Thesis Statement and Research Objectives .......... 10

2. RESEARCH DESIGN. . . . . . . . . . . . 15

Overview. ..................... 15

Study Sites. . . . . . . . . . . . . . . 15

Habitat. .................... 16

Surrounding uses. . . . . . . . . . . 17

Management of the orchards............ 19

Predation Trials. . . . . . . . . . . . . . . . 19

Trial periods. . . . . . . . . . . . . . . 24

Larval mortality determinations ............. 24

Bird Surveys. . . . . . . . . . . . . . . 27

Analytical Methods. . . . . . . . . . . . . . . . 29

3. RESULTS. ....................... 31

Overview......................... 31 
Predation Trials. . . . . . . . . 31

Total mortality. . . . . . . . . 31

Bird predation. ................... 31

Arthropod predation and parasitism.......... $\quad 32$

Disease .................... 32

Bird Surveys. . . . . . . . . . . . 33

4. DISCUSSION. ....................... 36

Overview........................ 36

The Big Picture .................... 36

Conclusion. . . . . . $4 \ldots \ldots \ldots \ldots \ldots \ldots \ldots \ldots$

Recommendations. .................. 43

APPENDIX $\ldots \ldots \ldots \ldots \ldots \ldots \ldots \ldots \ldots \ldots \ldots \ldots \ldots \ldots \ldots$

Table AI Deer Park Bird Surveys (Year 1$) \ldots \ldots \ldots \ldots 64$

Table A2 Happy Valley Bird Surveys (Year 1$) \ldots \ldots \ldots .66$

Table A3 Happy Valley Bird Surveys (Year 2)....... 68

Table A4 Bonny Doon Bird Surveys (Year 2)....... 70

LITERATURE CITED. . . . . . . . . . 71 


\section{LIST OF TABLES}

Table

1. Bird Species Found in Deer Park Orchard, Happy Valley Orchard, and Bonny Doon Orchard (Years $1 \& 2$ ), that are Cited as Important Codling Moth Predators in the Literature, and the Diets of Bird Species in the U.S. . . . . . . . . . . . . . 12

2. Status of Experimental Orchards (Years $1 \& 2) \ldots \ldots \ldots \ldots \ldots$

3. Major Plant Species \& Their Food Value for Birds Occurring in the Mixed Evergreen Vegetation Community Adjacent to Experimental Orchards (Years $1 \& 2) \ldots \ldots \ldots \ldots \ldots \ldots$

4. Number of Predation Trials, Larvae and Trees in Experimental Orchards (Years $1 \& 2) \ldots \ldots \ldots \ldots \ldots \ldots \ldots$

5. Beginning, Middle Examination(s), and Ending Examination Dates of Trials in Experimental Orchards (Years 1 \& 2) ..........

6. Transect Width, Length, and Number of Bird Surveys in Experimental Orchards (Years $1 \& 2) \ldots \ldots \ldots \ldots \ldots$

7. Aerial and Ground Foraging Guilds of Insectivorous Bird Species Recorded in Experimental Orchards (Years 1 \& 2).........

8. Codling Moth Mortality in Experimental Orchards (Years 1 \& 2)... 


\section{LIST OF ILLUSTRATIONS}

Figure

1. Locations of Experimental Orchards in Santa Cruz County ....... 46

2. Locations of Experimental Trees and Transects at Deer Park Orchard

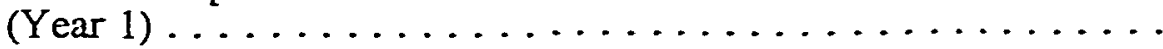

3. Locations of Experimental Trees and Transects at Happy Valley Orchard (Year 1 and 2$) \ldots \ldots \ldots \ldots \ldots \ldots \ldots \ldots \ldots \ldots \ldots$

4. Locations of Experimental Trees and Transects at Bonny Doon Orchard

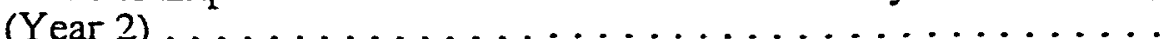

5. Remnants of a Codling Moth Cocoon Attacked by a Bird ........ 50

6. Codling Moth Percent Mortality and Survival at Deer Park Orchard (Year 1) . . . . . . . . . . . . . . . . .

7. Codling Moth Percent Mortality and Survival at Happy Valley Orchard (Year 1) . . . . . . . . . . . . . . . .

8. Codling Moth Percent Mortality and Survival at Happy Valley Orchard

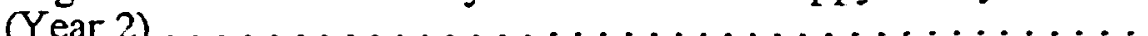

9. Codling Moth Percent Mortality and Survival at Bonny Doon Orchard

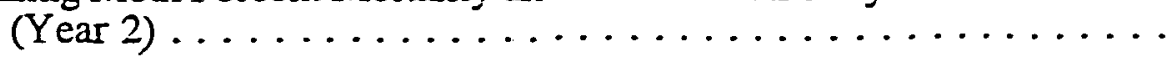

10. Average Number of Insectivorous Birds/Survey that Periodically or Continuously Forage in Trees in Three Experimental Orchards

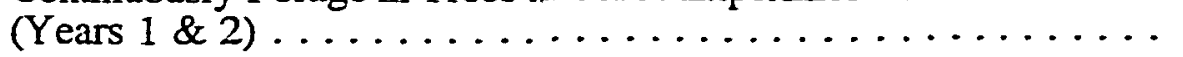

11. The Density of Insectivorous Bird Species in Experimental Orchards (Years 1 \& 2) . . . . . . . . . . . . . . . . . 56

12. Abundance of Insectivorous Birds in Experimental Orchards

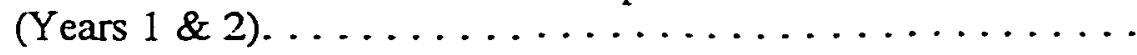

13. Index of Insectivorous Bird Species Diversity in Experimental Orchards (Years $1 \& 2) \ldots \ldots \ldots \ldots \ldots \ldots \ldots$

14. Insectivorous Bird Species Diversity as Related to Habitat at Happy Valley Orchard $($ Year 1$) \ldots \ldots \ldots \ldots \ldots \ldots \ldots$ 
15. Insectivorous Bird Species Diversity as Related to Habitat at Happy Valley Orchard (Year 2) .................. 60

16. Insectivorous Bird Species Diversity as Related to Habitat at Deer Park

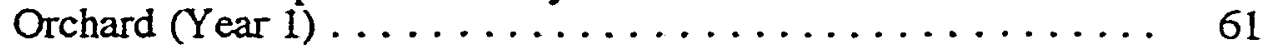

17. Woodpecker Feeding Strategy .................. 62 


\section{INTRODUCTION}

\section{Purpose of the Study}

Codling moth (Cydia pomonella), a major pest of apples and pears, is an increasing problem in orchards of walnut, prune, and a few varieties of plum (Flint, 1991). Birds and arthropods have been shown in other parts of the world to be part of the system of biocontrol that reduces codling moth numbers. This thesis examines predation of the overwintering stage of the codling moth in Central California Coastal apple orchards, an optimum time for bird predation and a time when insecticides are least effective.

Birds and agriculture can be allies. The agricultural value of birds was well known at the turn of the century, when the investigation of economic ornithology was conducted by the precursor agency to the USDA (Report of the Commissioner, 1885; McAtee, 1933). Even with this knowledge, agricultural activities and interests have contributed and continue to contribute to the decline of birds (Thelander, 1994). By 1979, over one third of California's native habitat was altered by agriculture (Donley et al, 1979), reducing bird species and habitat diversity. Pesticides undoubtedly add to the declines (Pimentel and Greiner, 1993). Organophosphates applied in orchards are found on bird's feathers, feet, and in their blood (Wilson et al., 1991).

Pesticides used with conventional farming practices contaminate food, air, and water, posing unknown hazards to human health. Residue analysis of U.S. apples detected pesticides in $63 \%$ of the samples tested (F.D.A., 1992, 1993, 1994). Simazine, an herbicide applied to apple orchards, has contaminated the drinking water of four U.S. cities (Cohen, Wiles and Bondoc, 1995). Winter fog in the San Joaquin Valley contains significant levels of pesticides including diazinon, a dormant spray treatment used on 
apples (Glotfelty, Seiber and Liljedahl, 1987). The synergistic effects of these and other pesticides in the environment are unknown, as are the effects of the breakdown products of pesticides.

Farming methods that incorporate biological practices to control pests decrease the use of pesticides in the environment. Apple growers in Northern California were able to reduce their use of guthion and other pesticides $63 \%$ by monitoring the codling moth life cycle and using pheromones and low risk oils (Benbrook, 1996). With about 1,300 acres of certified organic apples in Califomia, organic growers are also helping to lessen the pesticide impact (CCOF, 1998).

The conventional management of codling moth in apples has its own apparent problems and no long term solutions. Pesticides can cause secondary pest flare-ups when natural enemies are killed. For example, applications of a pyrethroid can produce secondary pest outbreaks of the two-spotted spider mite (Flint, 1991). Moreover, codling moth resistance to insecticides is occurring in South Africa where twelve to thirteen sprays per season of the pesticide guthion have made part of the insect population resistant ${ }^{1}$. Cross resistance of guthion to other materials is occurring in the U.S., where moth populations originally resistant to guthion are also showing resistance to pyrethroids (Stockwin, 1998).

Predators, parasitoids and pathogens will attack codling moth and can partially or wholly control this pest. In the Central Asian forests of Kazakhstan where apple trees and codling moth are native, the pest is controlled by its natural enemies, but adequate control outside its native setting has not been achieved ${ }^{2}$. Principles of biological control are at work when natural enemies reduce damage caused by noxious organisms (Debach and

'D. Thompson, then Representative for Pacific Biocontrol, discussed codling moth spray regimes at a Community Alliance with Family Farmers' Lighthouse Farm Network meeting in Watsonville in March 1996.

2 N. Mills, Professor, UC Berkeley, reviewed the origins of codling moth and discussed his work with its predators and parasites in Kazakhstan at the UCCE Walnut Grower's meeting in Hollister in February, 1996. 
Rosen, 1991), such as codling moth. Wasps (Hymenoptera) parasitize codling moth eggs; earwigs (Dermaptera) (Riddick and Mills, 1994) and spiders (Arachnida) (Falcon and Huber, 1991) attack eggs and hatching larvae; pathogenic micro-organisms such as Bacillus thuringiensis (BT) and granulosis virus (GV) are effective in some situations at killing the young larvae. Just prior to diapause, up to $44 \%$ of the codling moth larvae may drop to the ground (Glen and Milson, 1978; Wearing, 1975) where some may be preyed upon by carabid beetles (Carabidae) (Riddick and Mill, 1994) and nematodes (Brown, 1995).

One overwintering generation and two summer generations of codling moth usually occur in the Central Coast of Califomia. Spring moths fly in April to mate and lay eggs on the foliage of the apple trees. The larvae hatch and may feed on terminal leaves before finding their way into the developing fruit within twenty-four hours. Fifth instar larvae exit the apples, about ten to forty days later, to spin cocoons and have a short dormant period before pupating. These summer moths usually emerge in June or July, depending on the season. The moths mate, lay eggs and then the second generation of larvae eat their way into the fruit. In the late summer the larvae leave the apples and either crawl down to the older tree bark, where they hide in cracks and crevices, or drop to the ground, depending on the smoothness of the tree bark, the soil moisture and the organic matter on the surface of the soil to overwinter as larvae in the cocoons (Glen and Milson, 1978; Wearing, 1975). By April of the following year, the larvae pupate and emerge as moths to mate and begin the next cycle (Flint, 1991). It was during the overwintering diapausing larval stage of the moth (and for a short period, the pupal stage) that the field predation trials were conducted.

Organically approved, non-biological control practices exist to reduce the codling moth up to the fifth instar. The use of these practices, pheromones that disrupt reproduction and the applications of oil sprays that smother eggs, would lessen the infestation potential 
in the spring. Fifty-six to $100 \%$ of the codling moth that do not drop to the ground may remain in the trees through the winter to impact next year's crop if there are no other controlling factors (Glen and Milson, 1978; Wearing, 1975).

Few alternatives are available in the United States to control diapausing codling moths that spin cocoons in trees. During diapause, the moth is so well protected under the bark, and its respiration is so low, that even Class I conventional pesticides cannot destroy: this stage. Placing cardboard tree bands around the trunks of trees can be effective in certain situations in trapping overwintering larvae looking for a place to spin a cocoon, but it is a time-consuming process and usually only applied to smaller orchards.

Some insects are known to attack codling moth, or are thought to be important natural enemies of the codling moth in its diapausing stage. Ants (Formicidae) and certain beetles (Coleoptera) have been known to prey upon the larval cocoons (Jaynes and Marucci, 1947; Wearing, 1975; Wearing and Skilling, 1975; Hagley and Allen, 1988). Two wasp species are documented to parasitize the diapausing larvae ${ }^{3}$ and earwigs (Dermaptera) are thought to be important predators of this stage 4 .

Birds can also play a role in the biological pest management of codling moth. They can reduce pest populations during the cool season when they have an average of five months to find and consume the codling moth before it pupates. This is also the time when codling moths are at their lowest numbers in their life cycle (MacLellan, 1971).

Many insectivorous bird species have been reported to attack codling moth while gleaning the bark of apple trees (Besse, 1937; Falcon and Huber, 1991). McAtee (1911) reported 36 bird species as feeders of codling moth. A few well documented studies report statistical evidence of significant codling moth predation by birds in Canada, New Zealand,

${ }^{3}$ N. Mills, UCCE Walnut Grower's meeting in Hollister in February, 1996. .

4 Personal communication with R. Van Steenwyk, UC Berkeley Extension Entomology Specialist, June 1996. 
Poland and Britain (MacLellan, 1959; Mailloux and LeRoux, 1960; Wearing, 1975; Zajac, 1979; Solomon et al. 1976), but predation of overwintering codling moth by bird species in California has not been analyzed. This study is designed to provide data on the importance of bird and arthropod predation of codling moths in coastal apple orchards of Central California.

\section{Background}

Bird predation. Predation of codling moth by birds has been known for centuries. A 1746 report of this pest mentions the importance of birds:

They [codling moth] conceal themselves so thoroughly as scarcely to be found by men; but the woodpeckers and similar birds know how to discover quickly their retreats (Roesel von Rosenhof, 1746, 36).

Results from an economic ornithology program that examined bird predators of codling moth were reported 26 years after the work began. In 1885, the U.S. Agricultural Commissioner described a program that collected and examined birds' stomachs to determine which birds were beneficial and which were pests. In 1911 a USDA report described 12 species of birds found with codling moth in their stomachs, and another 24 species of birds as important predators (McAtee, 1911). The species whose stomachs contained codling moth included: downy woodpecker, Pacific-slope flycatcher, scrub jay, black-capped chickadee, bushtit, American robin, warbling vireo, orange-crowned warbler, black-headed grosbeak, Brewer's blackbird, northern oriole, and California towhee. Table 1 provides data from the literature on bird species that are important codling moth predators.

High rates of bird predation on codling moth occurs in the fall and winter when searching birds find diapausing insects in the apple bark. An Ontario study reported that approximately $67 \%$ of the wintering codling moth population was destroyed by 
woodpeckers (Boyce, 1941). In Nova Scotia, woodpeckers were able to reduce codling moth damage to a low enough level (along with other minor natural enemies) that the injury was below the economic threshold ${ }^{5}$ (MacLellan, 1959) (Table 1). In the latter study, biological control may have occurred because there are fewer codling moth generations per year in colder climates and, hence, there is less chance to build pest populations to damaging levels.

The variety of plant species in or around farms affects the number and types of bird species present, and increases potential codling moth predation by bird species. Bird and insect species richness also appears to increase with the diversity of crops on a farm, compared with a monocropped agricultural system (Chakravarthy, 1988). A study in Switzerland found that predation of codling moth increased where good nesting conditions existed (Savary and Baggiolini, 1955). Downy and hairy woodpeckers in Nova Scotia apple orchards were more abundant in orchards adjacent to native forests (MacLellan, 1961).

Researchers have estimated the rate of codling moth larvae susceptible to attack, or already preyed on, using different methods. Counting the amount of codling moth present on one vertical foot of the tree trunk from July to December, and walking transects to establish the numbers of woodpeckers and the limits of their feeding zones, showed that predation occurred on 52\% of overwintering codling moth cocoons (MacLellan 1958). In Quebec, collection of the loose bark of apple trees (by scraping the trunks) revealed the hiding place of diapausing codling moth. Bird predation of these cocoons measured 55$82 \%$, and mortality from frost and disease was recorded at $1-7 \%$. The birds responsible were hairy and downy woodpeckers, northem flickers, black-capped chickadees, and white breasted nuthatches (Maillox and LeRoux, 1960) (Table 1). Bark scraping in

${ }^{s}$ Economic threshold of a crop is the point at which control measures should be applied to prevent intolerable damage. 
southem Ontario documented bird predation rates of over $90 \%$, with arthropod predators, parasites and frost counting for the other 10\% (Hagley, 1969).

Bands placed as traps on tree trunks are used in orchards for estimating numbers of diapausing moths (MacLellan, 1958), as collection devices for the moths (Brown, 1995), and as a tool for measuring predation. A drawback of this method is that insectivorous birds learn to expect large numbers of hibernating larvae under trap bands and on trunks and branches of trees (Besse, 1937). Thus, studies that measure this type of bird predation may not give a true estimate, although they do reinforce the fact that birds consume codling moth. A study in Germany measured predation of over $90 \%$ of the codling moth population present under cardboard bands and on the barks of trees (Thiem and Sy, 1938). Similarly, ninety percent predation of codling moth in tree bands made of burlap was documented in Ohio, using exclusion cages for controls. The most common bird predators noted were the white-breasted nuthatch and the brown creeper (Stairs, 1985) (Table 1).

Researchers in New Zealand tagged codling moth larvae with cobalt-58 and released them on apple trees to measure predation and favored cocooning locations, and to document bird response. Eighty percent of the overwintering codling moth were eaten by silvereyes, and to a lesser extent, by European starling (Table 1). The moths preferentially choose the southern side of the tree to spin cocoons (in the Southem hemisphere) and were located about four to seven feet above the ground. Bird predation increased with height and if the cocoons were more accessible, such as under a bark chip instead of in a deep crevice (Wearing, 1975; Wearing and Skilling, 1975). Later, researchers determined that the predation was dependent on the density of the codling moth (Wearing and McCarthy, 1992).

By excluding birds from previously inoculated apple logs placed in cider-apple orchards, Solomon et al. (1976) found decreased numbers of the codling moth where bird 
predation was allowed. Up to $95 \%$ of the overwintering larvae on exposed logs were eaten, mostly by great tits and blue tits, and to a lesser extent by the tree creeper and European nuthatch (Table 1). Losses were low on the caged logs (Solomon et al., 1976).

The technique of excluding birds to determine predation levels has been used with a variety of insect species other than codling moth; the results have both confirmed the significance of bird predation and shown confounding effects because of predator interactions. The northern three-toed (Picoides tridactylus dorsalis Baird), downy, and hairy woodpeckers were found to be responsible for approximately 50-100\% reduction of Englemann spruce beetles on uncaged sections of tree trunks (Knight, 1958). Researchers found Lepidoptera larvae were more susceptible than other arthropod groups (Arachnida, Coleoptera, Homoptera, Hemiptera) to bird predation in exclusion experiments on striped maple trees (Holmes, Schultz and Nothnagle, 1979). In another study, density of insect larvae was 63\% higher where birds were excluded from bilberry stands (Atlegrim, 1989). Exclusion of birds from white oak saplings increased leaf area loss by $25 \%$ (Marquis, 1994). Other predators, such as spiders, may have confounded the effect of bird predation in a tropical Panamanian forest exclusion experiment because spider mortality was probably lower inside the exclosures (Gradwohl and Greenberg, 1982).

In an early study, Forbush (1921) assessed the value of bird predation on destructive insects in the United States at $\$ 444$ million. These calculations were based on $28 \%$ reduction of insect damage. At today's worth, this would equal over $\$ 4$ billion (Consumer Price Index, 1999).

Arthropod parasitism and predation. Parasitoids of codling moth can be an important part of a control strategy. Mills ${ }^{6}$ is currently raising parasitic wasps, Mastrus ridibundus and Liotryphon caudatus, as part of a classic biological release program in

${ }^{6}$ N. Mills, UCCE Walnut Grower's meeting in Hollister in February, 1996. 
California. In preliminary trials, $M$. ridibundus seems to be a more effective parasitoid than L. caudatus, and has attacked as much as $50 \%$ of the cocoons. In the past, Mailloux and LeRoux (1960) found about $1 \%$ of codling moth cocoons containing insect parasitoids in orchards of Quebec.

Ants have been documented attacking diapausing codling moth under cardboard bands and on trees. Seven species of ants, Solenopsis molesta Say, Monomorium minimum Buckley, Aphaenogaster fulva aguia Buckley, Tetramorium caespitum L., Phaidole pilifera Roger, Formica fusca Say, and $F$. pallide-fulva schaufussi incerta Emery, left specific signs of predation under cardboard bands in a West Virginia apple orchard (Jaynes and Marucci, 1947). Wearing (1975) noted the ant Chelaner antarcticus White attacking the overwintering codling moth in New Zealand orchards.

Beetles, spiders and earwigs are important predators of codling moth. Beetles (Carabidae) will attack fifth instar codling moth larvae (Riddick and Mills, 1994) as well as cocooned larvae. Cantharid beetle larvae have been recorded as feeding on codling moth in addition to some of the smaller carabid and ostomid larvae (Jaynes and Marucci, 1947; MacLellan, 1973). Spiders of ten comprise a large part of the predatory arthropod fauna in orchards. Many species of spiders are found on apple trees, depending on their predatory strategy of web building and waiting for prey, or actively hunting prey (MacLellan, 1973). Earwigs have been found to attack eggs and hatching codling moth larvae (Riddick and Mills, 1994) and are thought to be predators of the overwintering larvae ${ }^{7}$.

Pathogenic micro-organisms. Species of nematodes and bacteria can infect codling moth, but many may not be important factors in the regulation of the pest populations, especially in the diapausing stage. Nematodes will infect diapausing codling moth when placed in cardboard bands, but have limited effectiveness under natural conditions because

7 Personal communication with R. Van Steenwyk of UC Berkeley Extension, June 1996. 
of moisture requirements. Codling moth is susceptible to the bacterium, Bacillus thuringiensis (BT), that has been applied to the foliage, but since larvae spend less than 24 hours between hatching and boring into apples, the length of time the insects have to come in contact with, and ingest the BT is short (Flint, 1991). Glen (1982) reported 5-30\% of overwintering larvae were infected with pathogenic fungi, of which Verticillium lecanii Zimmerman was most important.

Similarly, fungi, protozoa, and viruses can infect codling moth but usually do not substantially affect the viability of the overwintering stage of the moth in the natural environment. The fungus, Beauveria bassiana, has been found responsible for codling moth mortality in many studies (Ferreira, 1943; Ferron and Vincent, 1978; Jaques and MacLellan, 1965; Hagley, 1971). Protozoa are found associated with codling moth naturally, but must be transmitted transovarially, and hence are not easily used as a control measure. Granulosis virus (GV) is effective at controlling larvae of codling moth, but only before it enters the cocooning stage (Falcon and Huber, 1991).

\section{Thesis Statement and Research Objectives}

This thesis examines bird and arthropod predation of diapausing codling moth, Cydia pomonella, using caged and exposed treatments in three Central California Coast apple orchards. Bird surveys answer quantitatively the question of how orchard management influences bird activity, and qualitatively the questions of how proximity to habitat affects bird activity, and which birds were thought to be important codling moth predators. 
This study is designed to test the following null hypotheses:

1) Exclusion of bird species from codling moth laden trees does not affect codling moth survival.

2) Bird activity, measured as species diversity, abundance, and the index of diversity, is the same in the abandoned and managed orchards. 


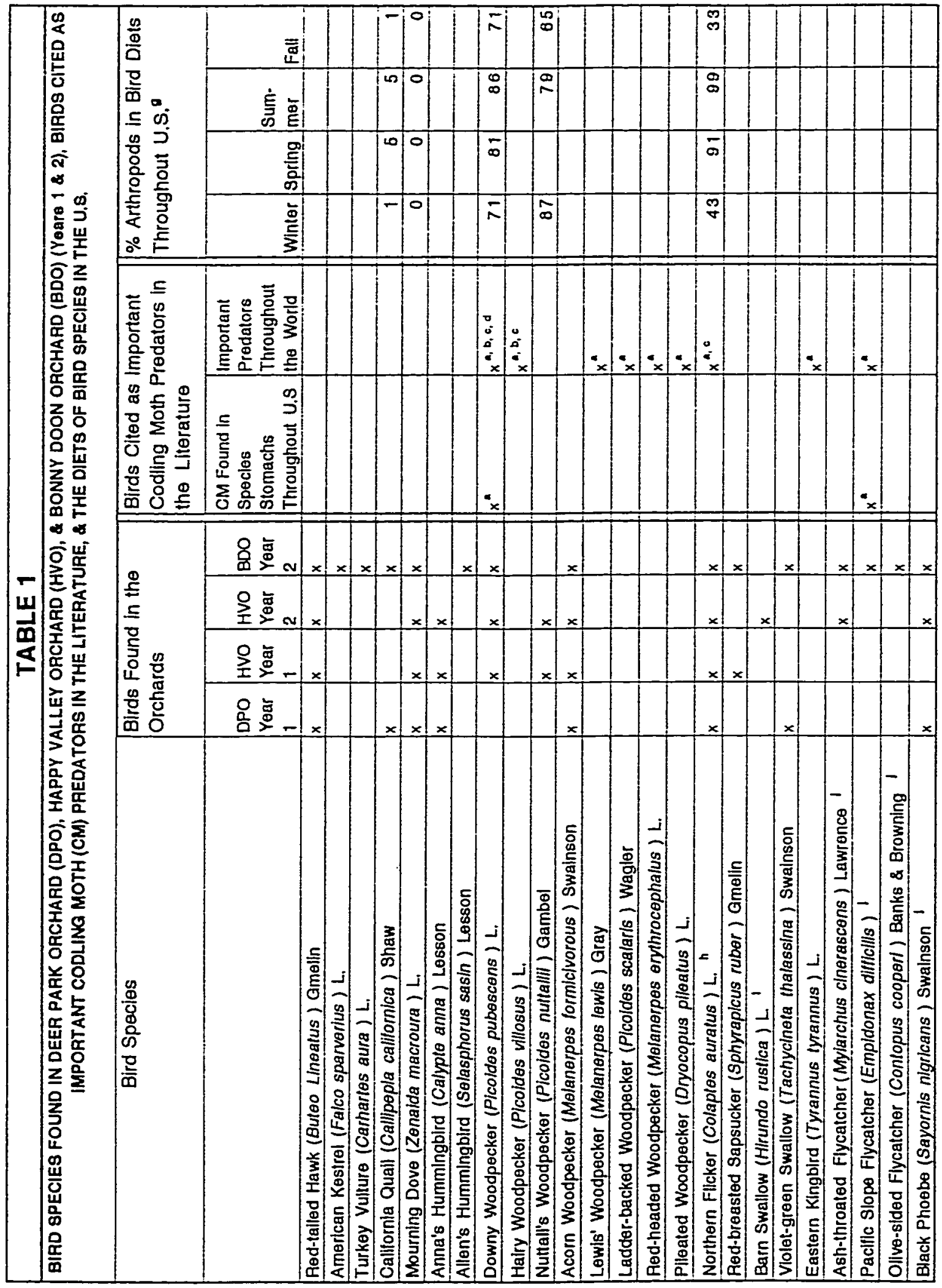




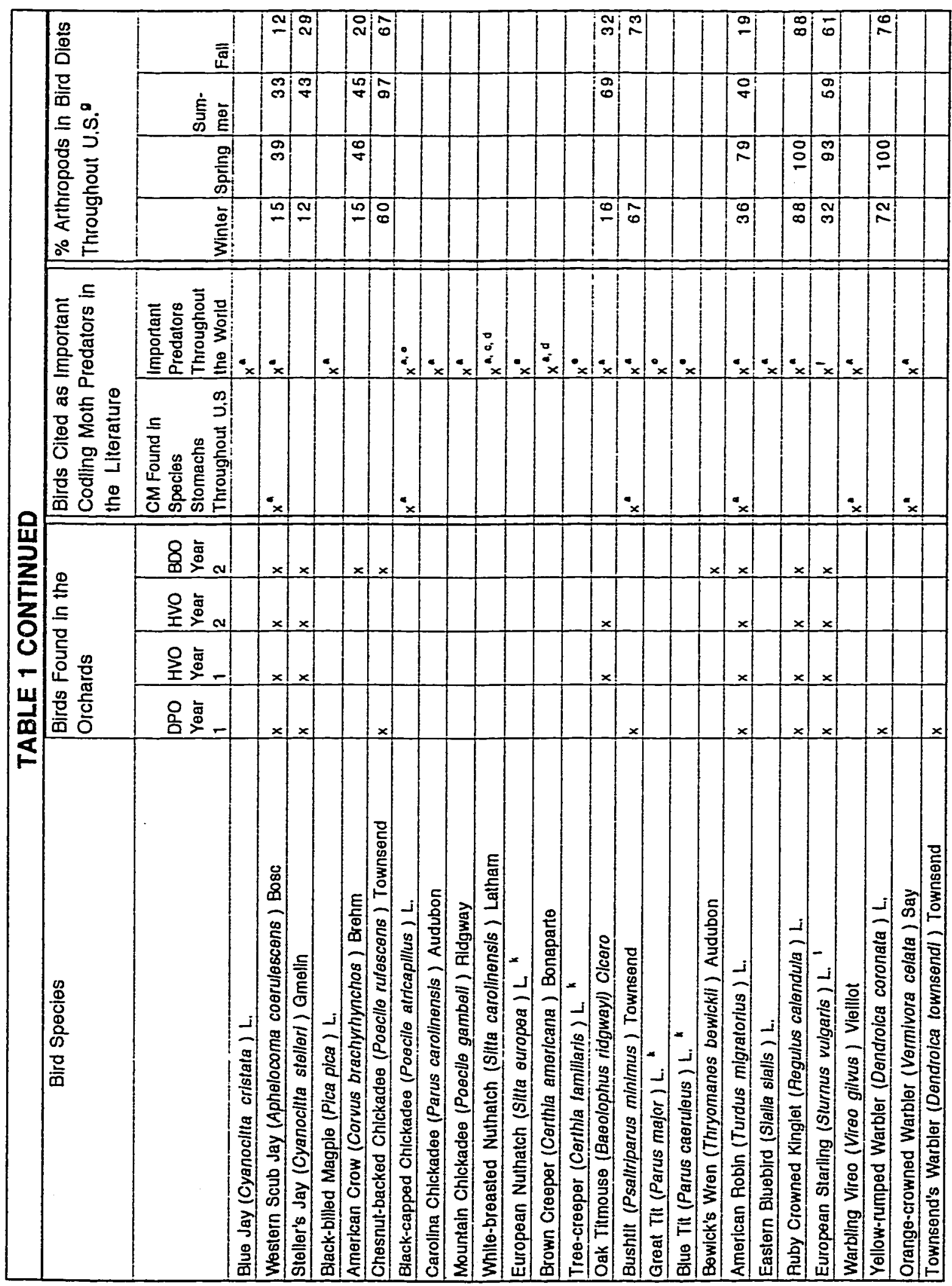




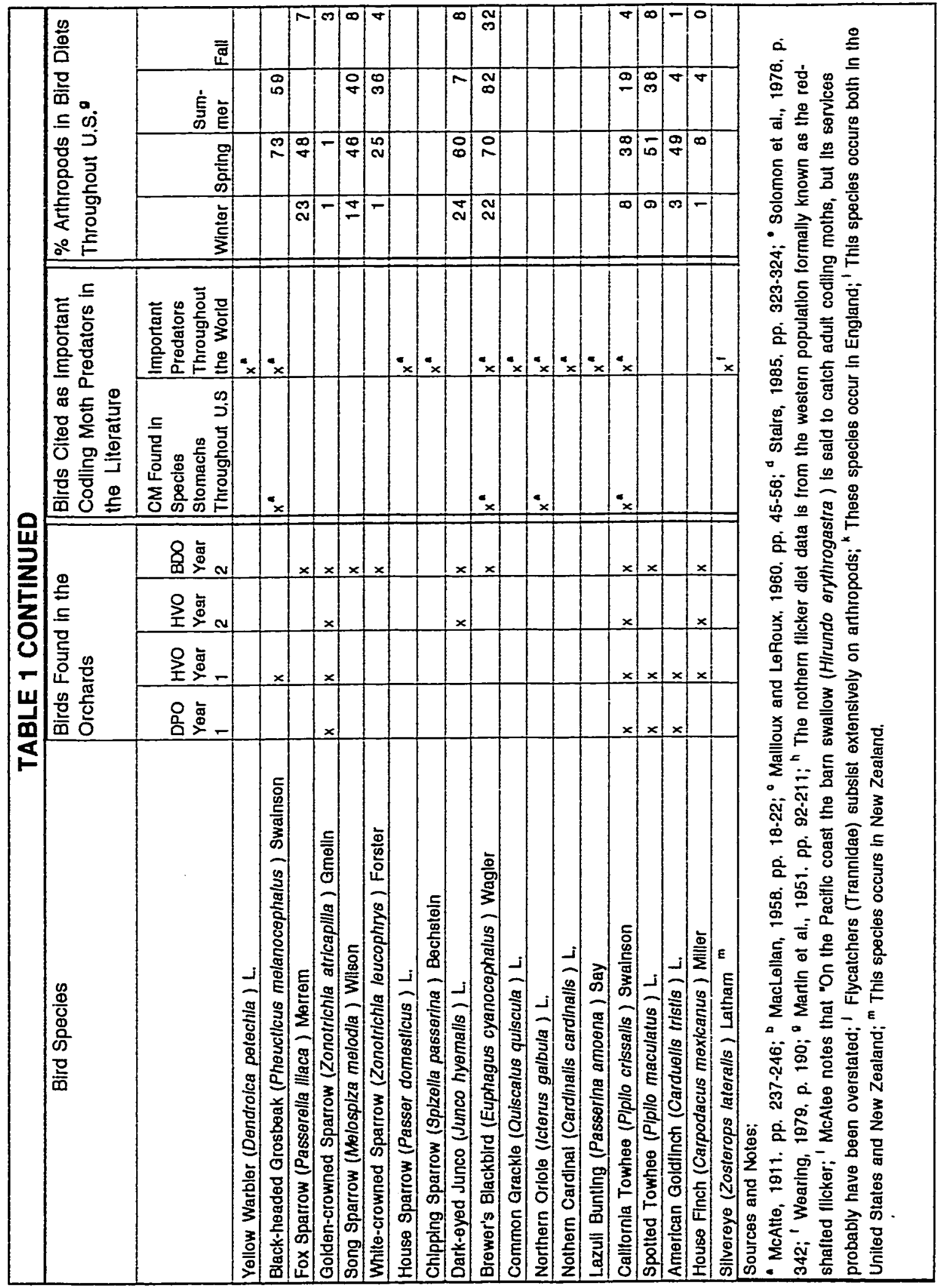


RESEARCH DESIGN

\section{Overview:}

This section describes the research design of experiments conducted over a two year period. First the sites are characterized. The bird exclusion experiments are then depicted. These were modified in the second year to benefit from lessons learned in year one. The bird survey techniques are described next. Larval mortality determinations were made to establish different signs of predation, and then the analytical techniques were described.

\section{Study Sites}

The study sites were located in Central Coast apple orchards of Santa Cruz County (Figure 1). The main criteria used in choosing these orchards were: 1) that the location be adjacent to, or sumounded by native habitat, to ensure an adequate bird population, and 2) that the orchard use no chemical management techniques that would interfere with the biological control methods. Two dry-farmed organically managed orchards were used in the summer, fall and winter of 1996. Deer Park orchard contained 7 acres of Pippin and Red Delicious apple trees, and Happy Valley orchard comprised 3 acres of mostly Pippin trees (a few Red Delicious and European Pears) (Figures 2 \& 3). The Happy Valley orchard and a 9 acre orchard containing mixed varieties of apples in the Bonny Doon area were used in the cool season of 1997-8 (Figure 4). The Bonny Doon orchard had been abandoned for at least 10 years. All three orchards would have been used in the second year, but the trees at Deer Park orchard were scheduled to be removed and replanted with another variety after the first year. Deer Park and Happy Valley orchards are at 
approximately 100 and 300 feet above sea level respectively, and Bonny Doon Orchard occurs at 1,500 feet in elevation. Table 2 summarizes salient features of the orchards.

\begin{tabular}{|c|c|c|c|}
\hline & & LE 2 & \\
\hline STATUS & F EXPERIMEI & L ORCHARDS ( & $\operatorname{ars~1\& 2)}$ \\
\hline Status of Orchards & $\begin{array}{l}\text { Deer Park } \\
\text { Orchard }\end{array}$ & $\begin{array}{l}\text { Happy Valley } \\
\text { Orchard }\end{array}$ & $\begin{array}{l}\text { Bonny Doon } \\
\text { Orchard }\end{array}$ \\
\hline $\begin{array}{l}\text { Managed or } \\
\text { Abandoned }\end{array}$ & Managed & Managed & Abandoned \\
\hline Size Of Orchard & 7 acres & 3 acres & 9 actes \\
\hline $\begin{array}{l}\text { Elevation (above } \\
\text { sea level) }\end{array}$ & 100 feet & 300 feet & 1,500 feet \\
\hline $\begin{array}{l}\text { Percent of Apple } \\
\text { Trees in Orchard }\end{array}$ & $\overline{72 \%}$ & $68 \%$ & $38 \%$ \\
\hline $\begin{array}{l}\text { Winter Vegetation } \\
\text { Cover }\end{array}$ & Cover crop & $\begin{array}{l}\text { Tall cover crop in } \\
\text { 1st year, sparse in } \\
2 \text { nd year }\end{array}$ & $\begin{array}{l}\text { High annual } \\
\text { weeds \& } \\
\text { colonizing shrubs }\end{array}$ \\
\hline $\begin{array}{l}\text { Summer Vegetation } \\
\text { Cover }\end{array}$ & None & None & $\begin{array}{l}\text { High annual } \\
\text { weeds \& } \\
\text { colonizing shrubs }\end{array}$ \\
\hline $\begin{array}{l}\text { Surrounding } \\
\text { Habitat To The } \\
\text { North }\end{array}$ & $\begin{array}{l}\text { Monterey pines; } \\
\text { Hwy } 1 \text { beyond }\end{array}$ & Oak woodland & $\begin{array}{l}\text { Annual grassland; } \\
\text { oak woodland } \\
\text { beyond }\end{array}$ \\
\hline $\begin{array}{l}\text { Surrounding } \\
\text { Habitat To The } \\
\text { East }\end{array}$ & $\begin{array}{l}\text { Acacia trees; } \\
\text { shopping center } \\
\text { beyond }\end{array}$ & $\begin{array}{l}\text { Open field; } \\
\text { redwoods beyond }\end{array}$ & $\begin{array}{l}\text { Annual grassland } \\
\text { and perennial } \\
\text { shrubs; mixed } \\
\text { evergreen habitat } \\
\text { beyond }\end{array}$ \\
\hline $\begin{array}{l}\text { Surrounding } \\
\text { Habitat To The } \\
\text { South }\end{array}$ & $\begin{array}{l}\text { Mixed evergreen } \\
\text { habitat }\end{array}$ & $\begin{array}{l}\text { Productive pear } \\
\text { orchard }\end{array}$ & $\begin{array}{l}\text { Smith Grade; } \\
\text { horse corrals \& } \\
\text { mixed evergreen } \\
\text { habitat beyond }\end{array}$ \\
\hline $\begin{array}{l}\text { Surrounding } \\
\text { Habitat To The } \\
\text { West }\end{array}$ & $\begin{array}{l}\text { Mixed evergreen } \\
\text { habitat }\end{array}$ & $\begin{array}{l}\text { Disturbed habitat } \\
\text { with coyote brush }\end{array}$ & $\begin{array}{l}\text { Pine Flat Road; } \\
\text { redwoods beyond }\end{array}$ \\
\hline
\end{tabular}

Habitat The three orchards used in this study were located in the Mixed Evergreen Vegetation Type (Barbour and Major, 1977), which occurs in the Coast Ranges at varying elevations of Central California. The mixed evergreen community is dominated by coast redwood, Douglas fir, coast live oak, interior live oak, canyon live oak, madrone, tan oak, 
with shrubs such as poison oak, blackberry, toyon, coyote brush, coffeeberry, ceanothus, and assorted understory sub-shrubs, herbs, vines and grasses. Table 3 lists the plant components of the unit that are found on the sites, and identifies which plant species have high food value for songbirds.

Surrounding uses. The surrounding environment at Deer Park, an actively farmed orchard, is composed of mixed evergreen vegetation from the south to west sides of the orchard. The native habitat on the south side is dominated by oaks with an understory of poison oak, blackberry and other sub-shrubs. The habitat to the southwest and west grades into conifer-dominated species of Monterey pine, coast redwood, and thinner undergrowth. On the north is a planted border of Monterey pines separating the orchard from the noisy corridor of Hwy. 1. To the east are large acacia trees separating the orchard from a shopping mall. Apple trees have died within the orchard and few have been replanted; $72 \%$ (280 extant trees out of 389 sites) of the trees are still alive (Figure 2).

Happy Valley, a working orchard, is located on a hundred-acre tract with an extensive pear orchard, over 15 homes, and has mixed evergreen vegetation interspersed throughout and surrounding the parcel. The apple orchard itself is adjacent to a thick canopy of cak woodland with few understory shrubs on the northeast. To the south and southeast exists a productive pear orchard with a redwood forest beyond. On the southwest and west side is disturbed native habitat with early successional vegetation of coyote brush. To the northeast and north is a former pear orchard composed of non-native annual grasses and herbs and a few dying pear trees; further up the slope is a mixed oak redwood forest. Some apple trees in the orchard are missing; $68 \%$ of the trees are present (267 extant trees out of 392 sites) (Figure 3). 


\begin{tabular}{|c|c|}
\hline \multicolumn{2}{|r|}{ TABLE 3} \\
\hline \multicolumn{2}{|c|}{$\begin{array}{c}\text { MAJOR PLANT SPECIES A AND THEIR FOOD VALUE FOR BIRDS b } \\
\text { OCCURRING IN THE MIXED EVERGREEN VEGETATION } \\
\text { COMMUNITY ADJACENT TO EXPERIMENTAL ORCHARDS } \\
\text { (Years } 1 \text { \& } 2 \text { ) } \\
\end{array}$} \\
\hline Trees & \\
\hline Big-Leaf Maple & Acer macrophyllum Pursh \\
\hline Madrone & Arbutus menziesii Pursh \\
\hline Tan Oak & Lithocarpus densiflora (Hook. \& Arn.) Rehder \\
\hline Monterey Pine $b$ & Pinus radiata D. Don \\
\hline Douglas Fir & $\begin{array}{l}\text { Pseudotsuga menziesii var. menziesii (Mirbel) } \\
\text { Franco }\end{array}$ \\
\hline Coast Live Oak ${ }^{b}$ & Quercus agrifolia Nee \\
\hline Canyon Live Oak ${ }^{b}$ & Quercus chrysolepis Liebm \\
\hline Interior Live Oak ${ }^{b}$ & Quercus wislizenii A.D.C. \\
\hline Coast Redwood & Sequoia sempervirens (D. Don) Endl. \\
\hline Shrubs & \\
\hline Coyote Brush & $\begin{array}{l}\text { Baccharis pilularis var. consanguinea (D.C.) } \\
\text { Kuntze }\end{array}$ \\
\hline Toyon & Heteromeles arbutifolia (Lindley) Roemer \\
\hline Coffeeberry & Rhamnus californica Eschsch \\
\hline California Blackberry b & Rubus ursinus Cham. \& Schldl. \\
\hline Poison Oak $\mathrm{b}$ & $\begin{array}{l}\text { Toxicodendron diversilobum (Torrey \& A. } \\
\text { Gray) E. Greene }\end{array}$ \\
\hline
\end{tabular}

Sources and notes:

a Barbour and Major, pp. 359-378.

b High value to birds. Martin et al., p. 482.

The abandoned Bonny Doon orchard has patches of trees interspersed with annual grasses and herbs, mostly non-native, coyote brush and other shrubs, and several ancient redwood stumps. Adjacent to the western boundary is Pine Flat Road, a moderately traveled rural road with two large redwood clumps spaced along the orchard border and a redwood forest on the other side. To the north, the property continues as a non-native grassland with a few apple trees before changing into a mix of oak woodland and landscape plants around a few buildings. On the east side is an annual grassland containing invading 
coyote brush, and beyond this area is an extensive mixed evergreen forest, with Monterey pines and redwoods. The southern boundary is Smith Grade, an infrequently traveled road with a few stands of redwood bordering its farther bank, and a house and property that grades into a broad mixed evergreen forest. Less than half of the apple trees throughout the orchard are present (38\%) (259 trees extant out of 688 sites) (Figure 4).

Management of the orchards. Deer Park and Happy Valley, both organically dryfarmed orchards, are managed for fertility, moisture conservation, and ease of harvest. In the fall of year one, and less so in year two, a nitrogen accumulating legume cover crop was planted that matured in mid-spring and was then disced under. A second discing removed any late spring annual weeds, which helped to conserve water for the trees and made harvesting the apples easier in the fall. From early summer to late fall, no vegetation grew under the trees.

As an abandoned orchard, Bonny Doon supports annual shrubs, herbs and grasses which grow unchecked. In the winter of year two, wild radish (Raphanus sativus), milk thistle (Silybum marianum) and Italian thistle (Carduus pycnocephalus) grew taller than six feet in much of the orchard. Newly established coyote brush and other shrubs are colonizing throughout the orchard. The apple trees have not been pruned for ten years or more and grow a thick tangle of branches made heavy with unthinned and virtually unpicked ripe apples in the fall. These branches periodically break off, a process that can eventually kill the trees.

\section{Predation Trials}

Codling moths were placed in the orchards under different treatments to investigate predation by birds and arthropods. In year one, predation of codling moth larvae was tested with three treatments. In one third of the trials, control larvae were exposed to predators; in 
one third, birds were excluded with $1 / 2^{n}$ wire mesh cages $(6 " \times 7$ " rectangular mesh molded into a ' $U$ ' shape, and attached with staples) and, in one third, larger insects were excluded with $1 / 16^{\prime \prime}$ mesh fiberglass window screen ( $5^{\prime \prime}$ square mesh overlaying a stiffer, guard-like mesh, and stapled). The caged and exposed treatments continued in year two. But, because there appeared to have been some bird predation through the $1 / 2$ mesh cages in year one, the mesh size decreased to $1 / 4^{\mathrm{n}}$ to keep out the most determined birds in year two. The screen trials in year two were eliminated because: 1) they increased the incidence of disease and 2) they were very hard to keep sealed in the wet winter.

Codling moth larvae were obtained from Nick Mill's lab, Environmental Science, Policy and Management Department, UC Berkeley. The lab raised the codling moth in conditions comparable to the fall equinox. Cool temperatures and short day lengths present in the lab physiologically triggered the larvae into diapause instead of quick pupation into moths.

The codling moth were placed on the orchard trees in the summer and fall of year one. The larvae were encouraged to spin cocoons in crevices of tree bark and under bark scales, by placing fifth instar larvae on the trees and covering each insect with a $1 \mathrm{oz}$. plastic cup (with the rim removed). The cup was caulked, glued and taped to the bark. After approximately one week, the larvae had spun a cocoon.

Early placement of the larvae at Happy Valley encouraged early and late moth emergence which led to unknown mortality in year one; therefore, improvements were made in year two to correct these factors. Larvae were initially placed in the Happy Valley orchard in July and August of the first year, but $60 \%$ pupated and emerged as moths while still under cups or screens, and were then replaced in mid-October. The placement of the larvae in the Deer Park orchard did not occur until late September. At the end of the predation trials, $39 \%$ and $15 \%$ of the larvae mortality was unknown at Happy Valley and 
Deer Park orchards, respectively, due to the difficulty in determining the difference between a predator attack and moth emergence. Emerging moths exit their cocoons through a small hole they create usually at one end of the cocoon (sometimes leaving the pupal case protruding out of the hole). Many of the moths may have accumulated enough degree days ${ }^{8}$ during the summer and fall to emerged in the winter, in a time when the weather would not be warm enough for them to mate. By placing the larvae in the orchards later in the fall, and ending the trials earlier in the spring, the unknown mortality factor was eliminated in the following year.

The procedure for placing codling moth in the trees also changed in the second year because of a larvae crop failure at UC Berkeley in the early fall. The next batch of codling moth would not have been at the proper stage until the weather had turned cold, so methods used by Solomon et al. (1976) were employed. The larvae were placed on apple logs indoors where temperatures allowed the insects to actively spin secure cocoons. Once properly outfitted, the codling moths and their logs were placed in the trees of each orchard. One half of the larvae were covered with cages which were larger ( $7^{\prime \prime} \times 9$ ') and made of a finer mesh (1/4" mesh) than the previous year. The logs had been obtained separately from each orchard and were made of mature wood with scaly bark. They measured about four feet long and at least three inches in diameter.

Height, cardinal direction and angle were taken into consideration in the direct placement of the codling moth on the trees in year one or in the placement of the logs in the trees in year two. The actual positions of the codling moth on the trees in year one were based on Wearing's findings from New Zealand (1975) that larvae spin cocoons more often at a height of 4 to 7 feet from the ground, and on the south side of the trees. The

\footnotetext{
8 A degree day is a physiological measurement unit that takes into account temperature and time when calculating insect growth rates. One degree day is equal to one degree above the lower developmental threshold over 24 hours (Zalom et al., 1983).
} 
larvae were placed on trees based on these findings, except that they were positioned on the north side of the trees, because the orchards are in the northern hemisphere. In year one, predation may have been made easier because more codling moths were placed on the top of slanted branches rather than underneath. The design in year two addressed this inconstancy and also incorporated another finding of Wearing's, that bird predation increases with height. The larvae were placed in the four cardinal directions on 3 to 4 logs per tree. Each log was placed in a tree, attached perpendicularly to live branches, and tied at the upper and lower ends. The logs were arranged in the trees in order to position some of the codling moths at approximately four feet and others at six to eight feet from the ground.

The total numbers of codling moths used per tree changed substantially between year one and two, but the total number per tree stayed within the range found in nature. The natural numbers of codling moths overwintering on the trees vary from only a few, to 15 or more. As indicated in Table 4, up to four larvae were placed on each experimental tree in the first year, one for each of the three treatments, and one of the treatments duplicated. Some of the four larvae died or never spun a cocoon before the trials began, which left certain trees with one or two treatments and others with four. Thirty three trees were used at Deer Park orchard with about 36 codling moths for each of the three treatments. Thirty trees were utilized at Happy Valley orchard with 26 larvae for each treatment.

In year two, also shown in Table 4, each experimental tree contained all of the same treatment (i.e. all exposed or all caged) and the numbers placed on each tree increased to a median of 13.5 codling moths per tree (four trees had six or seven codling moths per tree). The number of larvae per tree was increased to test whether bird predation would increase. Twelve trees were utilized in each of the orchards in year two. An average of 81 larvae for each of the two treatments were placed in the Happy Valley orchard and an average of 83 
larvae for each treatment were placed in the Bonny Doon orchard as shown in the table below.

\begin{tabular}{|c|c|c|c|c|c|c|}
\hline \multicolumn{6}{|c|}{ TUMBER OF PREDATION TRIALS, LARVAE AND TREES IN } \\
EXPERIMENTAL ORCHARDS (Years 1 \& 2)
\end{tabular}

Stratified random selections of the experimental trees in the orchards were based on the apple variety and adjacent habitat in Deer Park orchard and surrounding habitat in the other two orchards. In year one, a stratified random sample at Deer Park Orchard was made from the Pippin trees (excluding the Red Delicious trees) approximately ten to thirty meters (plus or minus half a tree width) from the mixed evergreen vegetation on the south and southwest side of the orchard. The trees were mapped and numbered, and numbers from a random number chart were selected until a Pippin tree the correct distance from the habitat was chosen. In both years at Happy Valley orchard, and in year two at the Bonny Doon 
orchard, a stratified random sample was made throughout the orchards minus the edge trees, since the high quality habitat roughly surrounds the orchards. The trees in these orchards were also mapped and numbered and a random number chart was used. Any initially selected tree that was dead or dying was replaced by a randomly selected viable tree.

Trial periods. The trials in year one began in the fall, were checked midway, and checked finally when they ended in the spring. The trials in year two were conducted during about the same time period as for year one, and they were checked an additional two times, as shown in the table below.

\begin{tabular}{|c|c|c|c|c|}
\hline \multicolumn{5}{|c|}{\begin{tabular}{|c|} 
TABLE 5 \\
BEGINNING, MIDDLE EXAMINATION(S), AND ENDING \\
EXAMINATION DATES OF TRIALS IN EXPERIMENTAL \\
ORCHARDS (Years 1 \& 2)
\end{tabular}} \\
\hline Year & Orchard & $\begin{array}{l}\text { Beginning } \\
\text { Dates }\end{array}$ & $\begin{array}{l}\text { Middle } \\
\text { Examination } \\
\text { Dates }\end{array}$ & $\begin{array}{l}\text { Ending } \\
\text { Examination } \\
\text { Dates }\end{array}$ \\
\hline One & $\begin{array}{l}\text { Deer } \\
\text { Park }\end{array}$ & $10 / 26 / 96$ & $1 / 16 / 97$ & $3 / 11 / 97$ \\
\hline One & $\begin{array}{l}\text { Happy } \\
\text { Valley }\end{array}$ & $11 / 23 / 96$ & $2 / 11 / 97$ & $3 / 9 / 97$ \\
\hline Two & $\begin{array}{l}\text { Happy } \\
\text { Valley }\end{array}$ & $11 / 26 / 97$ & $\begin{array}{l}12 / 21 / 97 \\
1 / 10 / 98 \\
2 / 9 / 98\end{array}$ & $2 / 27 / 98$ \\
\hline Two & $\begin{array}{l}\text { Bonny } \\
\text { Doon }\end{array}$ & $11 / 30 / 97$ & $\begin{array}{l}12 / 13 / 97 \\
1 / 2 / 98 \\
1 / 31 / 98\end{array}$ & $3 / 1 / 98$ \\
\hline
\end{tabular}

Larval mortalitv determinations. Larval mortality determinations were necessary to identify the different signs of predation. The determinations for bird predation were based on other researchers' descriptions of predation in year one, and additionally on hole sizes left in pieces of bark in year two (Figure 5). Wearing (1975) noted that the silvereye, 
makes a characteristic neat, round hole in the cocoon during feeding, or rips open one side of the cocoon. MacLellan (1971) stated that downy and hairy woodpeckers each leave distinctive beak marks on the bark when attacking the codling moth. Solomon describes bird predation:

The marks of (codling moth) predation by (British) birds are of ten plain to see: rounded holes going directly into the bark, oblique beak-marks and the scars of recently removed flakes of bark; and usually the greater part of the cocoon, or at least its underside, remains attached to the tree (Solomon et al. 1976, 342).

The characteristic bird peck through a piece of bark to a cocoon on the underside was used as a standard to judge the size of hole made by birds. Twenty-two bark chips with signs of bird predation attacks were measured. The mean hole size made by a bird was $3.4 \mathrm{~mm}$, the median was $3.2 \mathrm{~mm}$ and the range was $1.7 \mathrm{~mm}$ to $6.3 \mathrm{~mm}$.

If cocoons were partially or totally missing, they were attributed to an attack by a large predator, such as a bird, since a small predator would not be able to remove pieces of the cocoon without repeated effort, and for no obvious purpose. Larval mortality was attributed to birds if the cocoons were mostly missing, completely missing, had rips or holes (larger than $2.0 \mathrm{~mm}$ in year two only), or the bark chip covering the cocoon had a bird peck through it to the cocoon. The cutoff of $2.0 \mathrm{~mm}$ was made since distinguishing between $1.7 \mathrm{~mm}$ (the smallest bird peck noted in the bark chips) and $2.0 \mathrm{~mm}$ in winter field conditions could not be performed accurately.

Determinations for arthropod predation were based on a number of factors: the smallest size hole made in a cocoon by a bird, the nature and size of a hole left in a cocoon by an European earwig (Forficulidae), and by other researchers' portrayals of predation. The earwig predation observation was made by this researcher as part of a supplementary laboratory experiment of arthropod predation on codling moth cocoons. In this experiment, 
one earvig out of 46 total, was recorded attacking a diapausing codling moth ${ }^{9}$. A round hole $1.3 \mathrm{~mm}$ in diameter was measured in the cocoon. While one out of 46 does not indicate a strong preference for earwig predation of codling moth, the results were helpful in determining the appearance of predation. Signs of ant and beetle predation were characterized by Jaynes and Marucci (1947) from examinations of codling moth under cardboard bands in West Virginia apple orchards:

It is known that the cocoons with small holes were attacked only by (ants) ... cocoons that are entire but contain dead, burned larvae can be attributed to (two other ant species). Cocoons with large holes may be attributed to predator activity of all the Carabidae (beetles) in both the adult and larger larval stages and to the larva of Chauliognathus marginatus. The group with medium-sized holes represents possible predation by ants ... as well as some of the smaller carabid larvae and predaceous ostomid larvae (Jaynes and Marucci, 1947, 15-16).

Glen and Milson (1978) found that Carabid beetles would occasionally shelter beneath cardboard bands around trunks, but otherwise did not advance to higher parts of the trees, therefore beetle predation was unlikely in the experimental trials.

Larval mortality was ascribed to arthropods if the cocoon had a hole smaller than $2.0 \mathrm{~mm}$, or if it contained a parasitoid. It is possible that larvae could have first been parasitizied and then later consumed by a predator, in which case the amount of parasitation recorded would be lower than what actually occurred. In Happy Valley and Deer Park orchards, small ants were present and possibly responsible for some of the small holes measured. A larvae found dead, but not decaying was tabulated as unknown mortality since it could have died from ants or from a pathogen. Dead but not decayed larvae were found only in year one.

Codling moth disease mortality was described by Mailloux and LeRoux (1960) as being white in color, and hard and brittle when a fungi was responsible. Granulosis virus

9 Predators of codling moth, including the European earwig, were collected from the orchards and placed separately in a plastic cup with a diapausing codling moth. After one week, the cocoons were examined for signs of predation. 
$(\mathrm{GV})$ can cause the larvae to look as if it has melted. Some of the diseased larvae may be a result of an earlier attack by an unsuccessful or partially successful predator, and an opportunistic pathogen caused the mortality.

\section{Bird survevs}

Bird censuses were conducted from late November 1996 through early July 1997 of the first year and late September 1997 through late May 1998 of the second year, using the strip transect method. The transects were walked at a timed pace and all birds seen and heard within these strips were noted, including whether they were first observed in the air, on a branch, or on the ground. In the first year, 10 and 9 surveys were conducted at Deer Park and Happy Valley orchards respectively, and in the second year 7 and 6 surveys were made at Happy Valley and Bonny Doon orchards, respectively. David Suddjian, wildlife biologist and then President of the Santa Cruz Bird Club, accompanied the author on a winter morning survey to compare observations; only three species were present, two of them noted by the author, and all three noted by Suddjian.

Deer Park orchard transects were fixed at 20 meters wide (the width of 4 tree rows) and ranged from 225 to 310 meters long (Table 6). These four transects covered a little over half of the orchard and were located parallel to Highway 1 (Figure 2). The transects also paralleled the adjacent native habitat on the south and southwest. The transects included the region where the larvae were placed on experimental Pippin trees that are close to the native habitat.

Happy Valley orchard transects were 23 meters wide (the width of 4 tree rows) and approximately 80 meters long (Figure 3). The seven Happy Valley transects cover the complete orchard since the experimental trees were randomly located throughout all of the apple orchard (Table 6). 
Four transects, 20 meters wide and about 250 meters long, were marked at the Bonny Doon Orchard (Figure 4 and Table 6). These transects parallel Pine Flat road and are situated where most of the trees occur, since borders are not distinct due to senescence of the orchard.

\begin{tabular}{|c|c|c|c|c|c|c|}
\hline \multicolumn{7}{|c|}{$\begin{array}{c}\text { TABLE 6 } \\
\text { TRANSECT WIDTH, LENGTH, AND NUMBER OF BIRD SURVEYS } \\
\text { IN EXPERIMENTAL ORCHARDS (Years } 1 \text { \& } 2 \text { 2) }\end{array}$} \\
\hline Year & Orchard & $\begin{array}{l}\text { Transect } \\
\text { Width } \\
\text { (meters) }\end{array}$ & $\begin{array}{l}\text { Average } \\
\text { Transect } \\
\text { Length } \\
\text { (meters) }\end{array}$ & $\begin{array}{l}\text { Number } \\
\text { of } \\
\text { Transects }\end{array}$ & $\begin{array}{l}\text { Number } \\
\text { of } \\
\text { Surveys }\end{array}$ & $\begin{array}{l}\text { Total Area }= \\
\text { Transect Area } x \\
\text { No. of Surveys } \\
\text { (hectares) }\end{array}$ \\
\hline One & $\begin{array}{l}\text { Deer } \\
\text { Park }\end{array}$ & 20 & 262 & 4 & 10 & 20.96 \\
\hline One & $\begin{array}{l}\text { Happy } \\
\text { Valley }\end{array}$ & $\overline{23}$ & 80 & 7 & 9 & 11.59 \\
\hline Two & $\begin{array}{l}\text { Happy } \\
\text { Valley }\end{array}$ & 23 & 80 & 7 & 7 & 9.02 \\
\hline Two & $\begin{array}{l}\text { Bonny } \\
\text { Doon }\end{array}$ & 20 & 250 & 4 & 6 & 12 \\
\hline
\end{tabular}

A goal of the bird surveys was to determine which birds were likely responsible for codling moth predation. The foraging strategy (Ehrlich, Dobkin and Wheye, 1988) of the birds in the orchards was assessed to determine which predatory species were inclined to attack the exposed codling moth in the trees. To understand the relative diversity and abundance of codling moth predatory birds, a comparison was made between the species diversity, abundance, and an index of diversity in orchards. Only insectivorous bird species were included in those analyses.

A bird was included in the insectivorous subset if the bird, or its relatives, were reported to be important codling moth predators in other parts of the world, or if its diet (when known) was composed of a large percent of insect species. The birds that were recorded in the orchards but not covered in the analysis include three birds of prey (red- 
tailed hawk, American kestrel, turkey vulture), two game bird species (California quail, morning dove), and five songbird species (Allen's hummingbird, Anna's hummingbird, golden-crowned sparrow, house finch, American crow). Birds of prey consume vertebrates, while the game birds and hummingbirds ingest almost all plant material. Since one American Crow made a quick passage high above only one of the orchards and never landed, it was not included.

\section{Analytical Methods}

In order to determine if there were statistically significant differences between bird and arthropod predation and disease on protected versus exposed larvae, chi-square analyses were performed (Zar, 1996).

To assess the differences between the birds potentially responsible for codling moth predation in the abandoned orchard and the managed orchards, insectivorous bird data were analyzed for species diversity (the number of species) and abundance (the number of individuals). Species diversity and abundance were first calculated for each transect, and then the transect data were averaged per orchard and divided by the product of the transect area times the number of surveys conducted, to equal the average orchard data per area surveyed. This data reduction process resulted in too few data points to use parametric statistics (only 4 to 7 transect data per orchard). Non-parametric tests, Kruskal-Wallis and Mann-Whitney, were therefore used instead. The Kruskal-Wallis test was used to compare the differences between the orchards, and the Mann-Whitney test was used to compare the abandoned to the managed orchards.

An index of bird diversity was calculated using a transformation of the ShannonWeiner diversity index ( $\operatorname{Zar}, 1996$ ). The formula for this index is:

$$
H^{\prime}=\left(n \log n-\sum_{i=1}^{k} f_{i} \log f_{i}\right) / n,
$$


where $n$ is the sample size, $f_{i}$ is the number of observations in category $i$, and $k$ is the number of categories. The area per survey could not be factored into this analysis.

To determine the influence of habitat on the insectivorous bird species present in the orchards, bird diversity in each transect was graphed in relation to habitat, to give a graphical representation. 


\section{RESULTS}

\section{Overview}

This section presents the results of the predation trials and the bird surveys. First total mortality caused by all of the codling moth natural enemies is reported. The mortalities made separately by birds, arthropods, and disease, are then described. A qualitative assessment of the important insectivorous bird species surveyed is depicted next Finally, parameters of bird species diversity, abundance, index of diversity, and influences of habitat, which are analyzed from the bird survey data, are reported.

\section{Predation Trials}

Total mortality. In year one, total mortality at the Deer Park orchard was $19 \%$ for exposed, $14 \%$ for caged, and 14\% for screened. At Happy Valley mortality was $15 \%$ for exposed, $15 \%$ for caged, and $11 \%$ for screened larvae of each orchard. Unknown mortality factors for all three treatments averaged 15\% at Deer Park and 39\% at Happy Valley (Table 8, \& Figures $6 \& 7)$. Differences between treatments were not significant at Deer Park $\left(\mathrm{X}^{2}\right.$ $=1.43$, and $\left.X_{0.05,4}^{2}=9.49\right)$, or at Happy Valley $\left(X^{2}=8.30\right.$, and $\left.X_{0.05,6}^{2}=12.59\right)$.

In year two, total larval mortality at Happy Valley orchard was $83 \%$ (64/77) for the exposed treatments and $27 \%$ (23/85) for the caged treatments. Mortality was significantly greater for exposed larvae $\left(X^{2}=51.06\right.$, and $X_{0.001,1}^{2}=10.83$ ) (Table 8, \& Figure 8).

The total mortality at the Bonny Doon orchard for the exposed and caged treatments was $99 \%(74 / 75)$ and $77 \%$ (71/92). On 5 of the 6 exposed trees at Bonny Doon, $100 \%$ of the larvae were killed. The mortality was significantly greater for exposed treatments $\left(X^{2}=16.69\right.$, and $\left.X_{0.001,1}^{2}=10.83\right)$ (Table 8, \& Figure 9).

Bird predation. Bird predation at Deer Park and Happy Valley orchards was 19\%, and $11 \%$ respectively, in year one (Figures $6 \& 7$ ). Seventy-seven percent predation of the 
exposed larvae at Happy Valley and $91 \%$ predation of the exposed larvae at Bonny Doon was attributed to birds in year two, based on holes sizes in cocoons (Figures 8 \& 9). It appeared that some of the birds managed to prey on larvae through the exclusion cages. A chi-square analysis was conducted on the data from both orchards using these categories: a) the larvae that survived predation, $b$ ) the cocoons attacked by birds with holes greater than $2.0 \mathrm{~mm}$, and c) the cocoons attacked by arthropods with holes less than $2.0 \mathrm{~mm}$ and or larvae that were found dead from pathogens. The chi-square analysis showed significant differences between the exposed and caged trials for Happy Valley $\left(X^{2}=56.85\right.$, and $\mathrm{X}^{2}{ }_{0.001,3}=16.27$; therefore, reject $\left.\mathrm{H}_{\mathrm{O}}\right)$ and for Bonny Doon orchards $\left(\mathrm{X}^{2}=37.58\right.$, and $\mathrm{X}_{0.001,3}^{2}=16.27$; therefore, reject $\mathrm{H}_{0}$ ). These results suggest that excluding or allowing birds influenced arthropod predation and disease of the codling moth.

Arthropod predation and parasitism. Arthropod predation was measured in the exposed, caged, and screened trials at $0 \%, 11 \%$, and 3\% in Deer Park orchard respectively, and $4 \%, 4 \%$, and $0 \%$ in the Happy Valley orchard in year one respectively (Figures $6 \& 7$ ). In year two, 5\% mortality was attributed to arthropods in the exposed treatments and $6 \%$ mortality was recorded in the caged treatments of Happy Valley, whereas $5 \%$ and $12 \%$ mortality was ascribed to arthropods in the exposed and caged treatments at Bonny Doon, respectively (Figures 8 \& 9). The parasitoid wasp, Liotryphon caudatus, was found inside one of the caged cocoons at Happy Valley orchard, presumably a descendant from an earlier UC Berkeley release of these parasitoids ${ }^{10}$.

Disease. In year one, $11 \%$ of screened trials showed mortality because of disease at both Deer Park and Happy Valley orchard (Figures 6 \& 7). The screened treatment was problematic because the edges of the screens were hard to keep sealed and the incidence of

${ }_{10}$ N. Mills and his staff from UC Berkeley had released imported parasitoid wasps from Kazakhstan into the Happy Valley orchard in previous years. 
disease in these trials may have been caused by the sheltered and wetter conditions inside the screens. The screens were discontinued in the second year.

In year two at Happy Valley, only $1 \%$ and $2 \%$ mortality was attributed to pathogens in the exposed and caged treatments, whereas at Bonny Doon 3\% and $18 \%$ mortality was ascribed to pathogens in the exposed and caged treatments, respectively (Figures 8 \& 9).

\section{Bird Survevs}

All the birds recorded in the orchards are listed in the Appendix (Tables A1, A2, A3 \& A4) in two categories, insectivorous songbirds and non-insectivorous birds. The insectivorous songbird data was used in the analysis of foraging guilds, species diversity, abundance and in an index of diversity.

The relative importance of the 31 insectivorous bird species present in all three orchards was assessed in relation to foraging guilds. Figure 10 shows the average number of insectivorous bird species per survey in all the orchards and in all years that periodically or continuously forage in trees. Table 7, which lists the other insectivorous aerial and ground foraging species recorded in the three orchards, is presented separately from Figure 10 to highlight the birds most likely to be responsible for predation in the trees. Six species in Figure 10 and two species in Table 7, had been documented by McAtee in 1911 with codling moths in their stomachs (scrub jay, American robin, downy woodpecker, Brewer's blackbird, bushtit, black-headed grosbeak, Pacific sloped flycatcher, California towhee). Four different bird species (see Figure 10) recorded in the three orchards were found to be predators of codling moth by either McAtee (1911) or other researchers ${ }^{11}$ around the world (European starling, ruby-crowned kinglet, northern flicker, oak

"Refer to Table 1 to cross-reference which researchers reported these bird species. 
titmouse). Some of the remaining bird species present in the orchards are related to important codling moth predators indigenous to other locations globally.

\begin{tabular}{|c|c|}
\hline $\begin{array}{l}\text { AERIAL AND GRO } \\
\text { BIRD SPECIES }\end{array}$ & 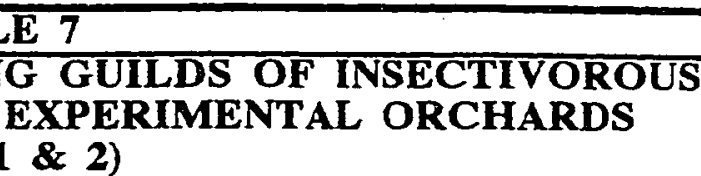 \\
\hline Aerial Forager & Ground Forager \\
\hline Pacific slope flycatcher ${ }^{a}$ & California towhee $^{\mathrm{a}}$ \\
\hline ash-throated flycatcher & spotted towhee \\
\hline olive-sided flycatcher & dark-eyed junco \\
\hline black phoebe & white-crowned sparrow \\
\hline barn swallow & song sparrow \\
\hline violet-green swallow & fox spartow \\
\hline
\end{tabular}

Source and note:

a According to literature (McAtee, 1911), bird species found with codling moth in their stomachs.

The density of insectivorous bird species is shown in Figure 11. Differences in species density between the abandoned orchard and the managed orchards was significant according to a Mann-Whitney test $\left(U=69.5\right.$, and $\left.U_{0.05},(1), 4,18=56\right)$. This suggested that bird species density is greater in the abandoned orchard. Differences between all the orchards were also significant according to a Kruskal-Wallis test $\left(H_{c}=10.37\right.$, and $\mathrm{X}_{0.05}^{2}$. $3=7.82$ ). The fewest total number of bird species (15) was recorded in Happy Valley orchard (Tables A2 \& A3), while the greatest total number (23) was documented in Bonny Doon orchard (Table A4).

The abundance of insectivorous birds in the abandoned orchard was significantly higher than in both managed orchards (Figure 12) according to a Mann-Whitney test ( $U$ = 62 , and $t_{0.05}(1), 4,18=56$ ), and the differences between all orchards were significant 
according to a Kruskal-Wallis test $\left(\mathrm{H}_{\mathrm{o}}=8.35\right.$, and $\left.\mathrm{X}_{0.05,3}^{2}=7.82\right)$. The lowest abundance of all birds (114) was recorded in Deer Park orchard in year one (Table A1), and the highest (172) was noted in Happy Valley Orchard in year two (Table A3).

The index of bird diversity appears higher in Bonny Doon orchard than in either of the managed orchards (Figure 13), although the size differences between the orchards was not factored in.

Insectivorous bird species diversity as related to habitat do appear to be distinct in year one at Happy Valley and Deer Park orchards, although this trend is not seen at Happy Valley in year two. An increasing gradient of species diversity is seen at Happy Valley in year one (Figure 14), from the transects closest to the disturbed habitat of coyote brush to the transects neighboring the higher quality cak woodland habitat. The trend at Happy Valley in year two is not apparent (Figure 15). At Deer Park orchard, transect one seems to have higher species diversity and it is adjacent to quality habitat (Figure 10). Habitat influences were not graphed for Bonny Doon orchard since it was surrounded by unmanaged grasslands and forests and semi-rural and rural roads which seem to equally influence the insectivorous bird species on all sides, and so the effect of habitat could not be determined.

Two bird species were observed nesting in cavities of apple trees during the experimental trials. A pair of chestnut-backed chickadees nested in the Deer Park orchard in the spring of 1996, and a pair of downy woodpeckers nested in the Happy Valley orchard in the spring of 1997. 


\section{DISCUSSION}

\section{Overview}

This section first discusses the importance of the results and how these findings relate to other reports in the literature. Next the concluding remarks summarize the most significant findings. Finally, recommendations for encouraging birds, and for further studies are made.

\section{The Big Picture}

The results of this study show that birds and to a lesser extent, arthropods can be important allies in reduction of codling moth in apple orchards. No predators were directly observed feeding on the codling moth, but of the 31 insectivorous bird species recorded in all three orchards, 12 had been documented by researchers ${ }^{12}$ around the world to attack the pest. Some of the remaining bird species present in the orchards are related to important codling moth predators indigenous to other locations globally. These known bird predators and/or their related family members presumably were attacking the codling moth in the caged treatments of the experimental orchards.

Diet is an important component in whether a bird species is predator or not. Bird diets consist of both animal and plant materials, and some birds, such as downy woodpeckers, have been recorded by Martin, Zim, and Nelson (1951) to consume over three-quarters of their diet from a variety of arthropods in a year. Figure 17 shows the specialized tongue a woodpecker species uses to extract its arthropod prey. Birds such as American robin were reported to consume arthropods chiefly in the spring when they are feeding their fast-growing young, although they continue to feed on a multitude of insects throughout the year (Martin, Zim and Nelson, 1951). A few birds such as scrub jays are

${ }_{12}$ Refer to Table 1 to cross-reference which researchers reported these bird species. 
listed in the UC IPM Apple and Pear guide (Flint, 1991) as pest species, even though they have been reported to consume one quarter of their diet in arthropods (Martin, Zim and Nelson, 1951). All three species were previously reported to have codling moths in their stomachs in McAtee's 1911 study, and all three were present in the author's experimental orchards. Some birds may prefer other arthropods over codling moth or they may use foraging strategies that do not detect this pest, but the percent artbropods in a bird's diet indicates the potential importance as a predator of codling moth.

Birds occupy distinct foraging guilds in the orchards and impact codling moth differently as a result. The majority of the California and spotted towhees' time is spent foraging in low-lying bushes or on the ground, and it is this type of forager that may be impacting codling moth diapausing in the ground litter. Aerial foragers, such as the Pacific slope, olive-sided and ash-throated flycatchers, may be consuming the adult codling moth on the wing. Some bird species are almost continuously foraging in the trees, such as rubycrowned kinglet, downy woodpecker, oak titmouse, and chestnut-backed chickadee (Ehrlich, Dobkin and Wheye, 1988). Others forage both in the trees and on the ground, including scrub jay, American robin, European starling, Steller's jay, and northern flicker. These part - and full-time tree foraging species are the most likely predators of the experimental codling moth trials of this research project.

Just as foraging strategies define a species presence in part of the orchard, so do nesting and roosting requirements. Cavity nesters, such as downy woodpecker, chestnutbacked chickadee, and oak titmouse, require either a new site to excavate every year or need a previously hollowed-out cavity. Dead limbs of apple trees, more abundant in the abandoned orchard, may be actually preferred to live wood, as they are more easily drilled. American robins require a site to build a cup nest and bushtits need a location to hang their sac-like nest. Two-thirds of the insect-loving bird species found in the experimental 
orchards nest in the region, while the other one-third migrate to breed. All require roosting sites in or within reasonable flying distance of the orchards. When a bird's basic requirements are met nearby or within an orchard, it is more likely to be present. Year-round presence in the orchards is not a factor in whether birds are effective codling moth predators. Both resident and non-resident species were present in the experimental orchards to impact the overwintering codling moth. Non-residents are specialists and take advantage of predictable periods of local food abundance. The rubycrowned kinglet is present in the orchards from fall to the spring just when diapausing codling moth is most abundant, and the ash-throated flycatcher appears in the orchards in the spring and summer when the adult codling moths are flying. The chestnut-backed chickadee, oak titmouse, downy woodpecker, American robin, and jay species, among others, are present year-round to impact the codling moth. These results are consistent with other research in apple orchards around the world. Migrating birds were primarily responsible for predation in British, Polish and New Zealand orchards (Glen and Milsom, 1978; Zajac, 1979; Wearing, 1979), while resident birds were the key predators in Canadian orchards (MacLellan, 1959).

More insectivorous bird species were recorded in the abandoned orchard, which had a higher diversity of annual grasses, herbs and shrubs, than were observed in the managed orchards. An index of bird species diversity also rated the abandoned orchard the highest, although the timing of the bird surveys, which began earlier in the fall for year one and ended later in the summer for year two, may have somewhat skewed the results by one to three migrant species at either end of the surveys. Abundance of insectivorous birds in the abandoned orchard was more than in the managed orchards. These findings of increased species diversity and abundance are consistent with Chakravarthy's (1988) report that bird species richness increased when a farm contained a diversity of plants and insects 
within and surrounding it. Thus maintaining diverse habitats may attract birds to orchards and thereby encourage predation of codling moth.

Species diversity of insectivorous birds appeared to be influenced by habitat quality at Happy Valley and Deer Park orchards in year one (Figures $14 \& 16$ ), but not in Happy Valley in year two. What plant species are present, what the habitat structure is, and what the percent vegetative cover is, all influence the local diversity of birds (Gill, 1989). The food value, nesting and roosting sites in quality habitat, especially the oak woodland community (Bakker, 1972) at Happy Valley, is undoubtedly attractive to the birds, which seemed to come into the orchard more of ten from this locality in year one. A somewhat greater density of apple trees was present in the middle of the Happy Valley, as opposed to the edges of the orchard, which may have complicated the results in the second year (Figure 3). These findings of habitat influence, though somewhat inconclusive, are in line with MacLellan's report (1961) that downy and hairy woodpeckers are more plentiful in orchards near native forests.

Birds' behavioral responses of increasing predation as density of the pest increases may be occurring in these orchards. Predation was much lower in the first year when only one or two larvae were exposed per tree, as opposed to the second year, when the number of larvae per tree increased to an average of 14 per tree. Predation increased substantially, from averages of $15 \%$ to $84 \%$, as the number of prey increased. Many other factors may explain this relationship, but Canadian, European, and New Zeaiand researchers have also documented bird behavioral responses to increases in codling moth population (MacLellan, 1971; Solomon and Glen 1979; Thiem and Sy, 1938; Zajac, 1979; Wearing and McCarty, 1992).

Birds' foraging responses can be influenced by surrounding types and amounts of food. Maximum foraging was not reported in high yielding mealworm prey patches by the 
European Great tit; the birds periodically checked low yielding patches which then resulted in an easy switch when the density of the high yielding patch dropped (Smith and Sweatman, 1974). Additionally, maximum foraging responses may only occur when the nutritional quality of the food source is adequate, and there is enough cover from avian predators (Stiling, 1992). Zajac (1979) found that codling moth predation was influenced by artificially increasing the amount of food available to birds, in both orchards with high initial pest numbers and in conventional orchards with few numbers. The combined amounts of codling moth and supplemental food present in the Polish orchards resulted in more intensive foraging by the birds (Zajac, 1979). Food quality and abundance may be important factors in density dependent predation of the author's experimental orchards, and some bird species may be more inclined than others to this phenomenon depending on foraging strategies.

Significant predation differences between the codling moth treatments were not detected in year one due to a large amount of unknown moth mortality, probably caused by early winter pupation during the trials. Also in year one, no recorded significance was possibly related to the density dependent phenomenon that resulted in little predation on the few codling moths present per tree. In year two, significant differences in the trials were found. Significance in year two was influenced by the lack of winter pupation, and the density dependent phenomenon that resulted in increased predation on the larger numbers of codling moths per tree.

The ecotone between orchard edges and habitat may be an important area for bird predation because of the increased number of codling moth typically found there in both organic and conventional systems ${ }^{13}$. Recruitment of codling moth from locations outside the orchards increases the populations along the border area, as does the use of

${ }^{13}$ Personal communication with D. Thompson, Representative for $3 \mathrm{M}$ Incorporation's codling moth pheromones, February 1999. 
pheromones ${ }^{14}$. When pheromones are applied, the center of the orchard is saturated, but the scent is not as strong on the edges, where the codling moth populations can build. Thus orchard edges would benefit from density-dependent predation by bird species.

Bird species population dynamics may or may not be affected by conventional or ecologically based management; bird predation of arthropods in other parts of the world has been documented in both systems. Songbird species density in a conventionally managed prune orchard was shown by Geupel and King (1998) to be about equal to the biointensively managed orchard, and to have a lower index of diversity and higher abundance. Predatory birds consumed codling moth in conventional Canadian, British and Polish research apple orchards (MacLellan, 1959; Solomon et al., 1976; Zajac, 1979), where pesticides were used on part or all of the study sites, and were also present in a New Zealand research orchard where ryania (a botanical pesticide) was used (Wearing, 1979). The results of this author's research in organic orchards of the Central Coast should be transferable to conventional orchards in the region.

Ants, wasps, beetles, spiders, and earwigs were potential predators and parasitoids present in the experimental orchards. Spiders and earwigs were found on the tree bark, as were the ants. Beetles were usually present in the ground litter and were occasionally found on the lower section of the trunk. None of these natural enemies, except a wasp species, were the known moth larvae predators or parasites, although some were implicated either by their close proximity to dead larvae, or the size of holes in the empty cocoons.

Arthropod predation and disease may be amplified when birds are excluded. The increase in mortality caused by arthropods and disease as seen under the cages in the abandoned orchard (refer to Figure 9) appears to result from excluding birds as the primary

${ }^{14}$ Codling moth pheromones are synthetic substances that mimic the scent secreted by the female codling moth to attract a mate. The scent is so pervasive, especially in the middle of the orchard where it is less windy, that the male is confused, which results in less codling moth pressure. 
predators that were suppressing the secondary mortality agents. This reduction of competition and replacement of the bird niche by the arthropods and pathogens was not seen in the Happy Valley orchard (Figure 8), perhaps because the diversity in this managed orchard was not as great and does not support as many mortality mechanisms. Happy Valley orchard had sparse ground cover in year two compared to the abandoned orchard which had wild radish, milk and Italian thistle over 6 feet tall. These results concur with Altieri and Schmidt's (1986) report that the number of natural codling moth enemies was less in an orchard with no ground cover than with one that was well-vegetated (with cover crops). Thus, artbropod predation and disease may best serve as back-up mortality agents when bird predation is low, such as in an orchard surrounded by miles of monoculture, where diversity of secondary mortality agents is high because of a cover crop and interplantings of native plant species.

\section{Conclusion}

Bird and arthropod predation has been shown to be part of an orchard system that can reduce codling moth, rather than completely controlling this pest. Many of the bird species recorded in the surveys are known to consume codling moth diapausing on trees, especially those that are arboreal foragers. Birds impact the codling moth during the wintering stage when pesticides are least effective, and may be instrumental in reducing the higher codling moth density on the edges of conventional or organic orchards. These insectivorous bird species appear to increase in diverse orchards and in orchards near native habitat. Arthropods and disease seem to impact the codling moth in diverse orchards, chiefly when birds are not present. By conserving habitat in and around the orchard which supplies diverse food, reproductive, and cover resources, growers can provide favorable conditions for birds, arthropods, and disease whose prey or host includes codling moth. 


\section{$\underline{\text { Recommendations }}$}

Apple growers should conserve native bird habitat adjacent to their orchards, and increase habitat by planting native shrubs and trees within and surrounding the orchards. Leaving a few dead limbs in the apple trees, that are manicured so as not offer hiding places for overwintering codling moth, will furnish woodpeckers with excavation nest sites. Placing nest boxes in orchards will supply downy woodpeckers with roost sites during the winter (Ehrlich, Dobkin and Wheye, 1988), and will provide chestnut-backed chickadees nest sites in the spring.

Small orchards surrounded by native habitat report more fruit damaged by birds than larger orchards adjacent to native habitat ${ }^{15}$. Most birds are not pests in apple orchards. One of the few exceptions is the house finch, which has a diet high in plant material and probably is not a codling moth predator. Another exception is the scrub jay, which is both a known predator of codling moth, and can be a pest during apple season. The benefits of the scrub jay should be weighed against the damage it can cause to the fruit; every diapausing female moth consumed by a jay will not produce an average of 60 progeny that could damage fruit. If either bird species is a problem in a small orchard, bird netting can effectively protect the crop in the summer as the apples mature.

By creating or conserving native plant habitat, growers will encourage bird predation, and pesticide use will be reduced. There will be less need for pesticides in conventional orchards due to the increased impact on codling moth populations, especially on the edges of the orchards where moth populations are generally higher. Decreasing pesticide use will result in less chemical residues on food, less air and water-borne

15 Growers discussed bird damage to apple crops at a Community Alliance with Family Farmers' Lighthouse Farm Network meeting in Watsonville in March 1999. Smaller orchards seem to be impacted more by birds, possibly due to the larger ratio of edge to orchard area. 
chemicals in the environment, less pesticide exposure to birds, and less destruction of beneficial arthropods in orchards.

Future research should be conducted in California orchards to determine whether an increase in bird predation is dependent on codling moth density, and if supplemental food affects these predator-prey density factors. Orchard management strategies that incorporate plant diversity, such as annual cover crops and perennial hedgerows, should be tested to see how they affect bird predation, arthropod predation, and the interactions between bird and arthropod predators. Studies should be made to determine whether attracting insectivorous cavity nesting birds, such as the downy woodpecker and the chestnut-backed chickadee, is an effective strategy for reducing codling moth. 
TABLE 8

CODLING MOTH MORTALITY IN EXPERIMENTAL ORCHARDS (Years (1 \& 2)

\begin{tabular}{|c|c|c|c|c|c|c|c|}
\hline \multirow[t]{2}{*}{ DEER PARK ORCHARD TRIALS Yeer 1} & \multicolumn{2}{|c|}{ Exposed } & \multicolumn{2}{|c|}{ Caged } & \multicolumn{2}{|c|}{ Screened } & \multirow[t]{2}{*}{$\begin{array}{l}\text { Total No. } \\
\text { of } \\
\text { Larvae }\end{array}$} \\
\hline & Number & Percent & Number & Percent & Number & Percent & \\
\hline LARYAE USED IN TRAALS & 37 & & 36 & & 36 & & 109 \\
\hline \multicolumn{8}{|l|}{ Larval Mortality After Cocooning } \\
\hline Larval Mortality from Birds & 7 & $19 \%$ & 1 & $3 \%$ & & & \\
\hline Lavad Mortality from Arthropods & & & 4 & $11 \%$ & 1 & $3 \%$ & \\
\hline Larval Mortality from Pathogen & & & & & 41 & $1 \%$ & \\
\hline Total Larval Mortality & 71 & $10 \%$ & 5 & $14 \%$ & 51 & $14 \%$ & 17 \\
\hline No Mortattity & 26 & $70 \%$ & 26 & $72 \%$ & 24 & $67 \%$ & 76 \\
\hline Mortality Factor Unknown & 41 & $11 \%$ & 5 & $14 \%$ & 71 & $19 \%$ & 16 \\
\hline HAPPY VALLEY ORCHARO TRIALS Year 1 & \multicolumn{2}{|c|}{ Exposed } & \multicolumn{2}{|c|}{ Caged } & \multicolumn{2}{|c|}{ Screened } & \\
\hline LARVAE USED IN TRIALS & 26) & & 26 & & 27 & & 79 \\
\hline & & & & & 1 & & \\
\hline \multicolumn{8}{|l|}{ Larval Mortality Aftor Cocooning } \\
\hline Larval Mortality from Birds & 3 & $11 \%$ & 2 & $7 \%$ & & & \\
\hline Larval Mortality from Arthropods & 1 & $4 \%$ & 1 & $4 \%$ & & & \\
\hline Larval Mortarty from Pathogen & & & 1 & $4 \%$ & 3) & $1 \%$ & \\
\hline Total Larval Mortally & 41 & $15 \%$ & 41 & $15 \%$ & 3 & $11 \%$ & 11 \\
\hline No Mortatlity & g) & $35 \%$ & $7 !$ & $27 \%$ & 16 & $59 \%$ & 32 \\
\hline Moth Emergence & 3 & $12 \%$ & 2 & $8 \%$ & $0 !$ & $0 \%$ & 5 \\
\hline Mortality Factor Unknom & 10 & $38 \%$ & 13 & $50 \%$ & 8) & $30 \%$ & 31 \\
\hline HAPPY YALLEY ORCHARD TRIALS YEAT 2 & \multicolumn{2}{|c|}{ Exposed } & \multicolumn{2}{|c|}{ Caged } & & & \\
\hline LARVAE USED IN TRIALS & 77 & & 85 & & & & 162 \\
\hline \multicolumn{8}{|l|}{ Larval Mortality After Cocooning } \\
\hline Laval Mortality from Birds & 59 & $77 \%$ & 16 & $19 \%$ & & & \\
\hline Larvad Mortality from Arthropods & 41 & $5 \%$ & 5 & $6 \%$ & & & \\
\hline Larval Mortality from Pathogen & 1 & $1 \%$ & 2 & $2 \%$ & & & \\
\hline \multicolumn{8}{|l|}{$\begin{array}{l}\text { Larval Mortality Unknown But Dead - } \\
\text {-Larvae Were Found }\end{array}$} \\
\hline Total Larval Mortality & 64 & $83 \%$ & 23 & $27 \%$ & & & 87 \\
\hline No Mortatity & 13 & $17 \%$ & 82 & $73 \%$ & & & 75 \\
\hline BONNY DOON ORCHARD TRIALS YeER 2 & \multicolumn{2}{|c|}{ Exposed } & \multicolumn{2}{|c|}{ Caged } & & & \\
\hline LARVAE USED IN TRIALS & 75 & & 82 & & & & 167 \\
\hline \multirow{2}{*}{\multicolumn{8}{|c|}{ Larval Mortality After Cocooning }} \\
\hline & & & & & & & \\
\hline Lavval Mortality from Arthropods & 4 & $5 \%$ & 11 & $12 \%$ & & & \\
\hline Larval Mortality from Pathogen & 2 & $3 \%$ & 17 & $18 \%$ & & & \\
\hline \multicolumn{8}{|l|}{$\begin{array}{l}\text { Larval Mortality Unknown But Dead - } \\
\text {-Larvae Were Found }\end{array}$} \\
\hline Totad Larval Mortalty & 74 & $98.7 \%$ & 71 & $77 \%$ & & & 145 \\
\hline No Mortatily & 11 & $1 \%$ & 21) & $23 \%$ & & & 22 \\
\hline
\end{tabular}




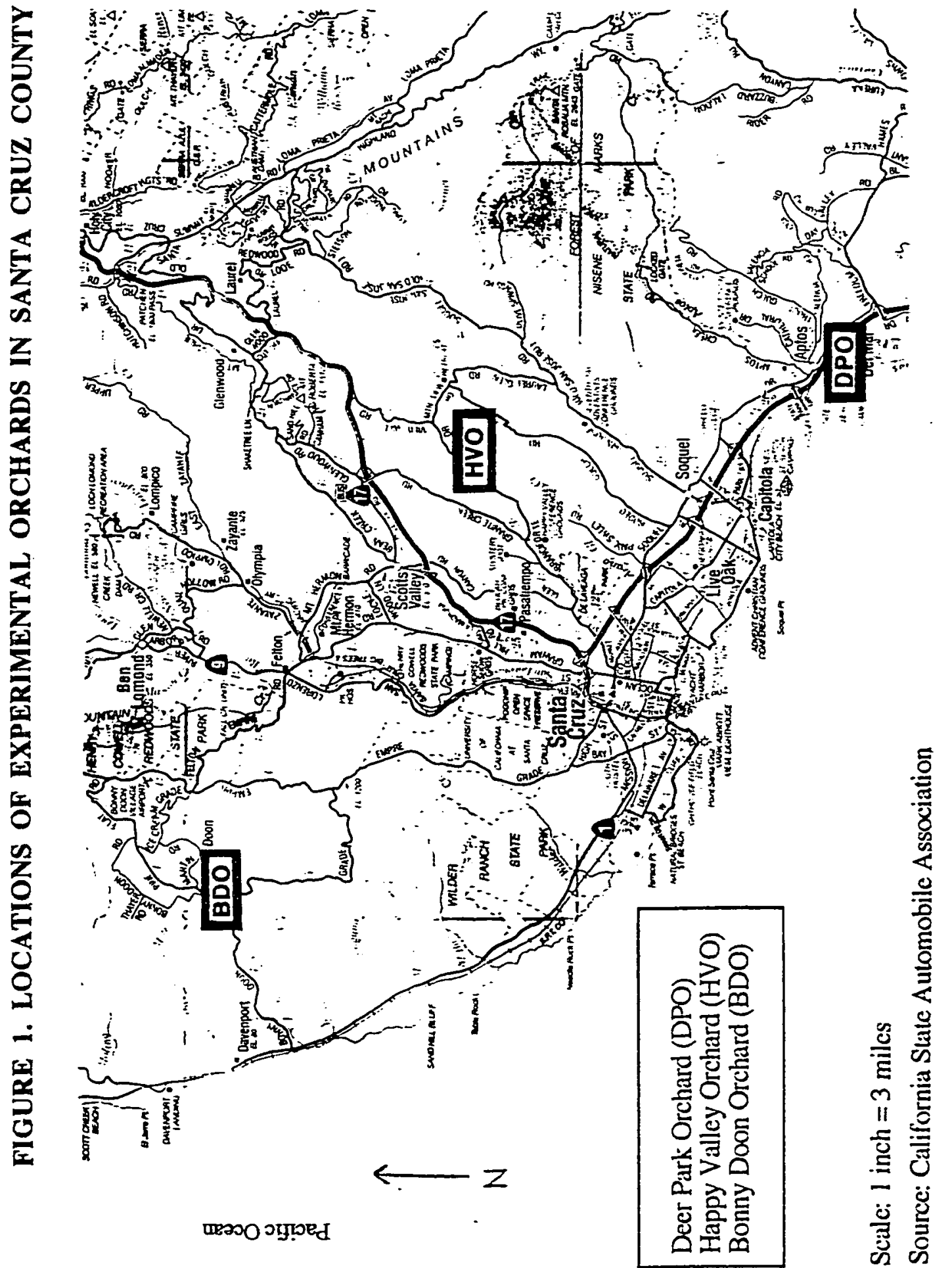



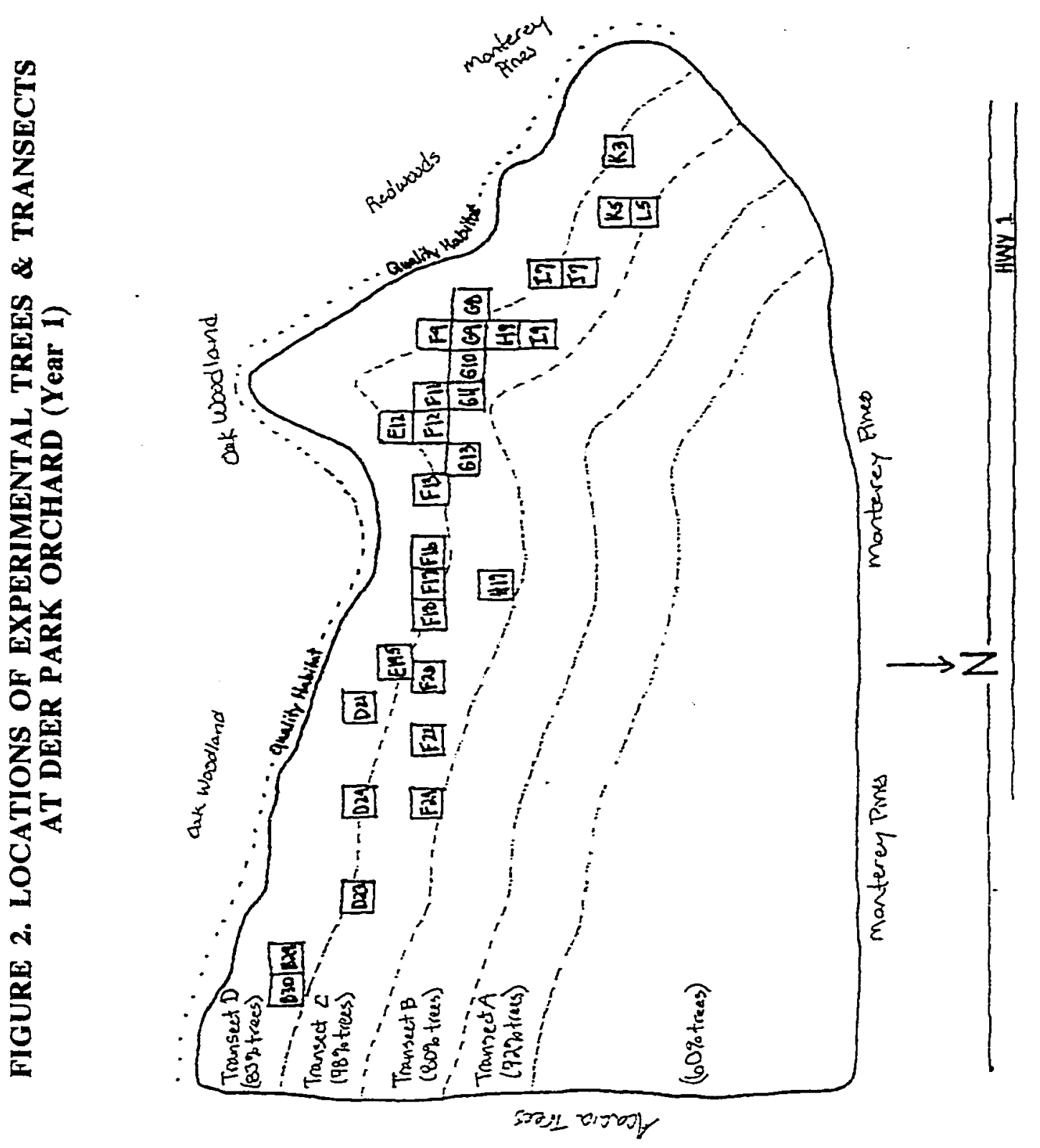

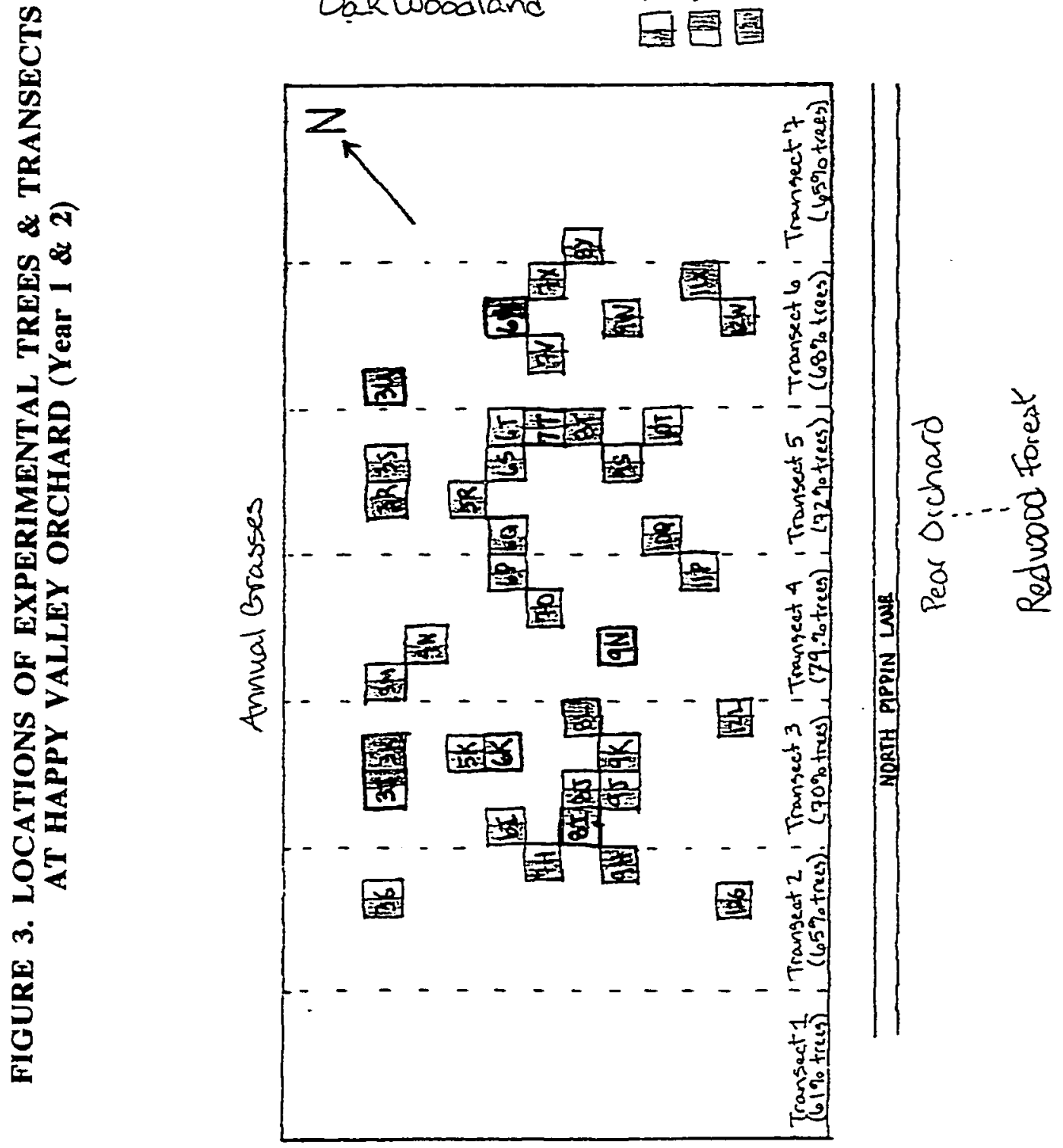

yonse glohos 


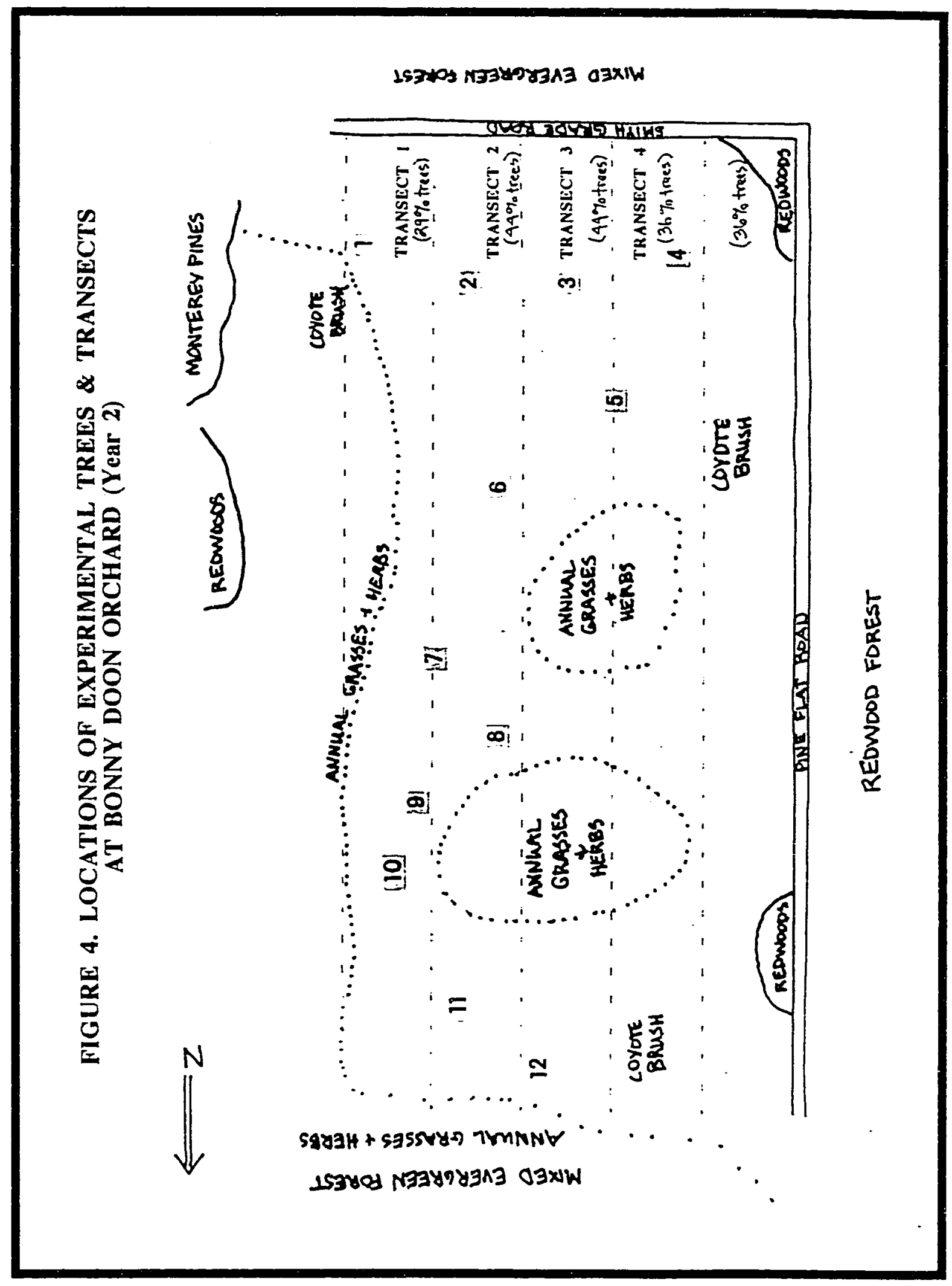


FIGURE 5. REMNANTS OF A CODLING MOTH COCOON ATTACKED BY A BIRD

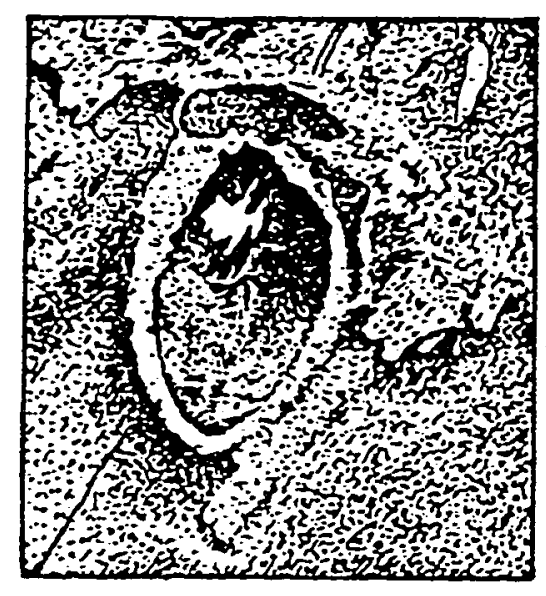

This turn-of-the-century drawing shows an inner bark surface with the outlining remains of a codling moth cocoon and a hole in the bark made by a Woodpecker species.

Source: Forbush, 1908, p. 251. 


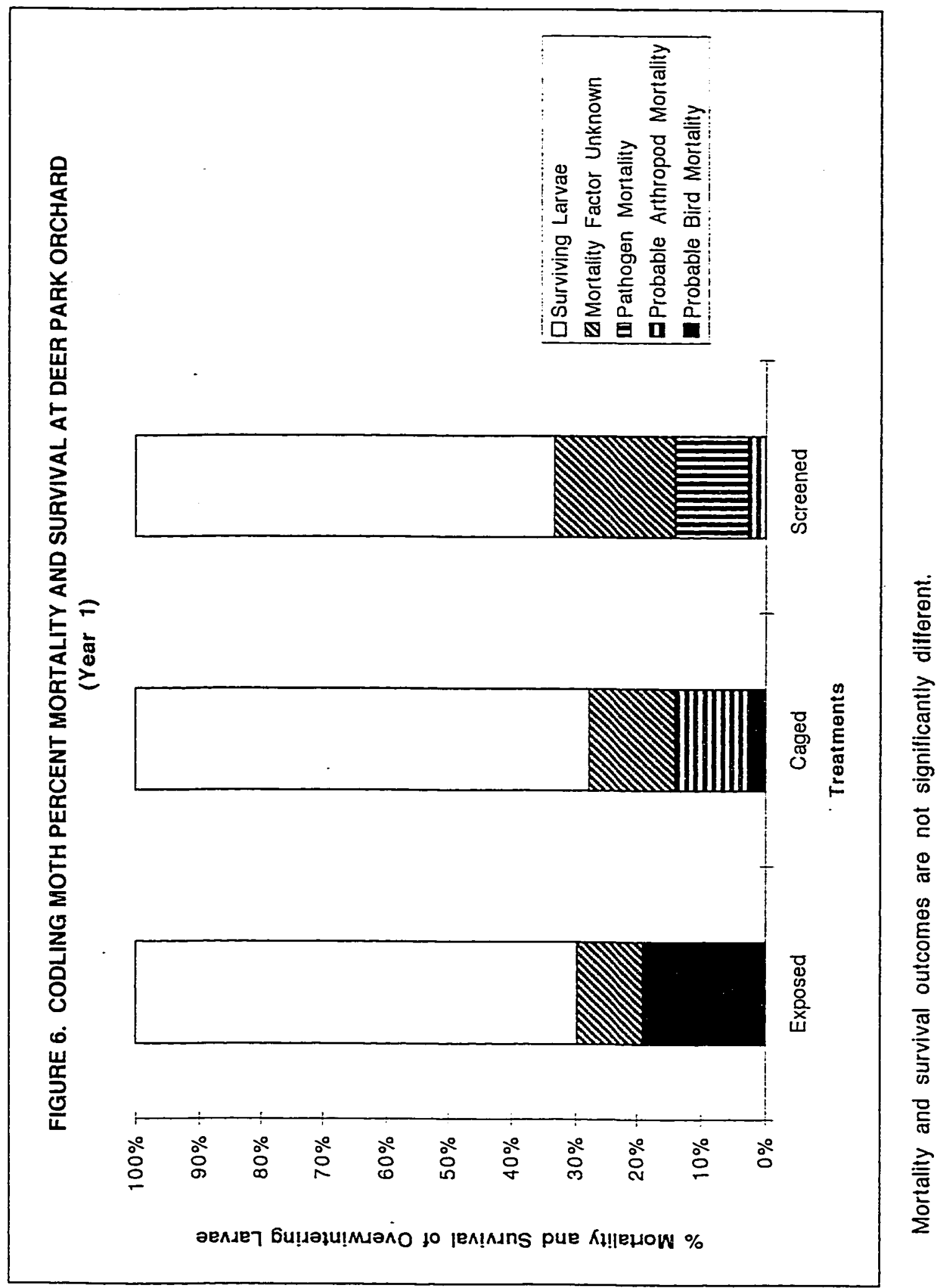




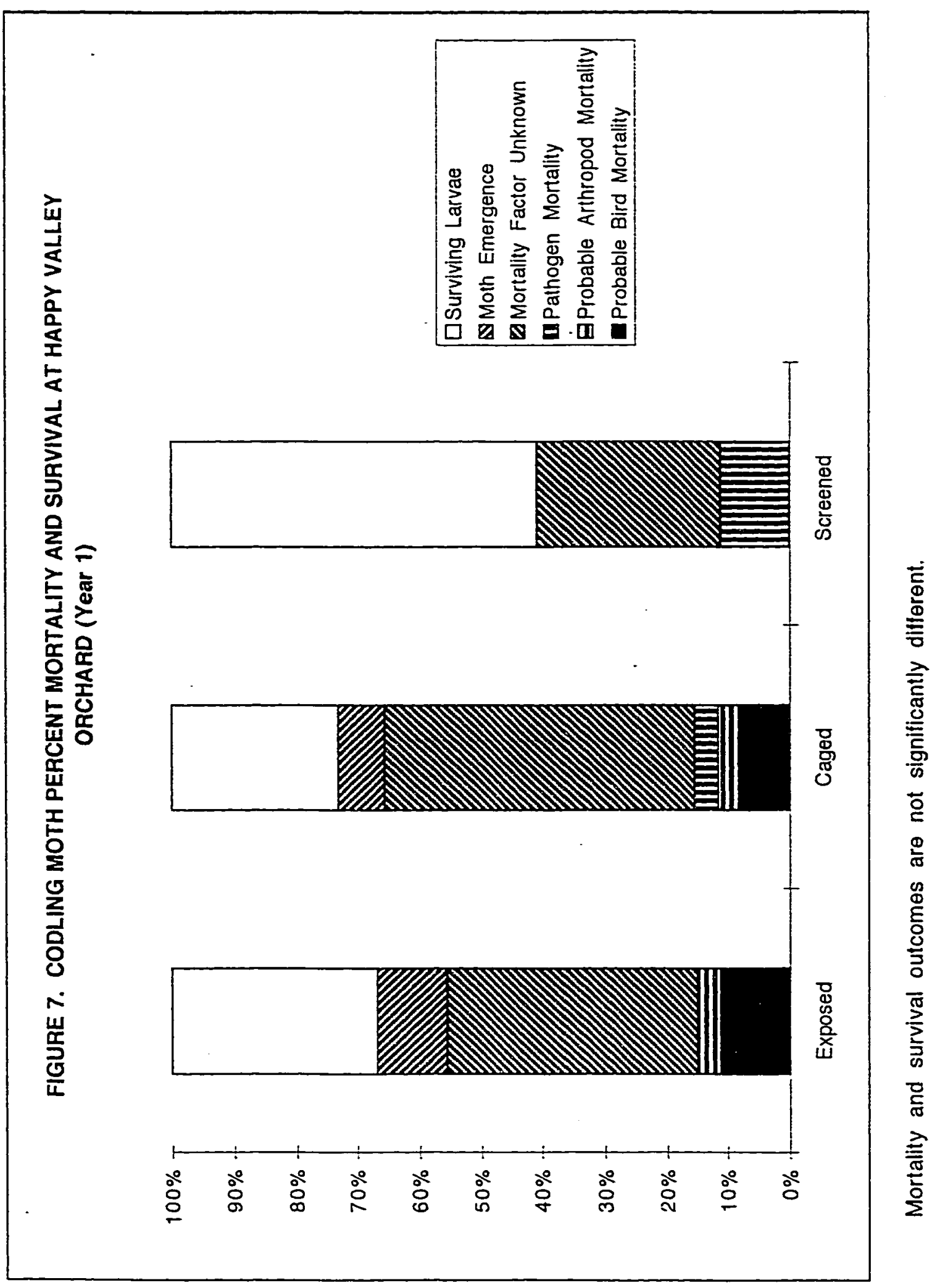




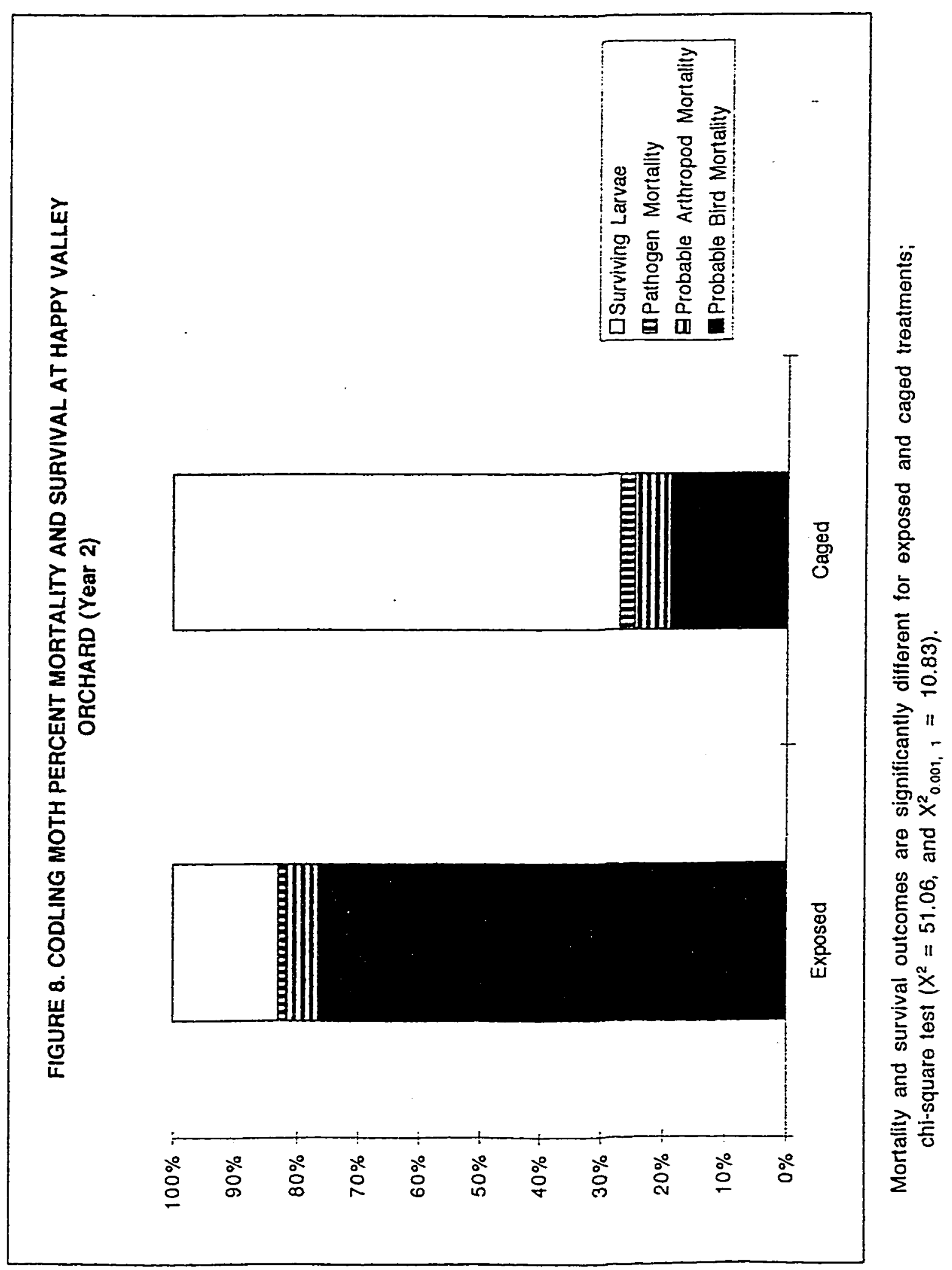




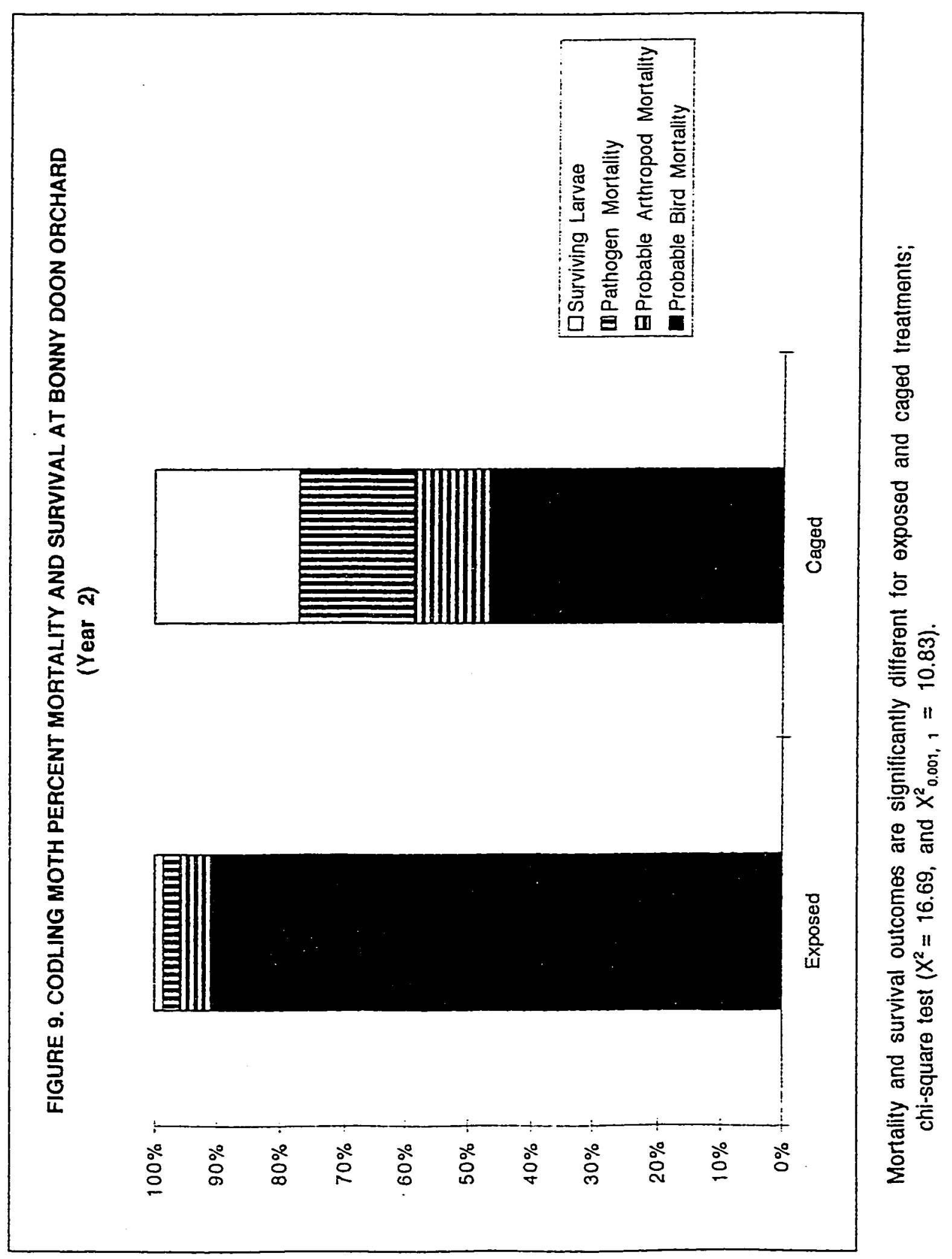




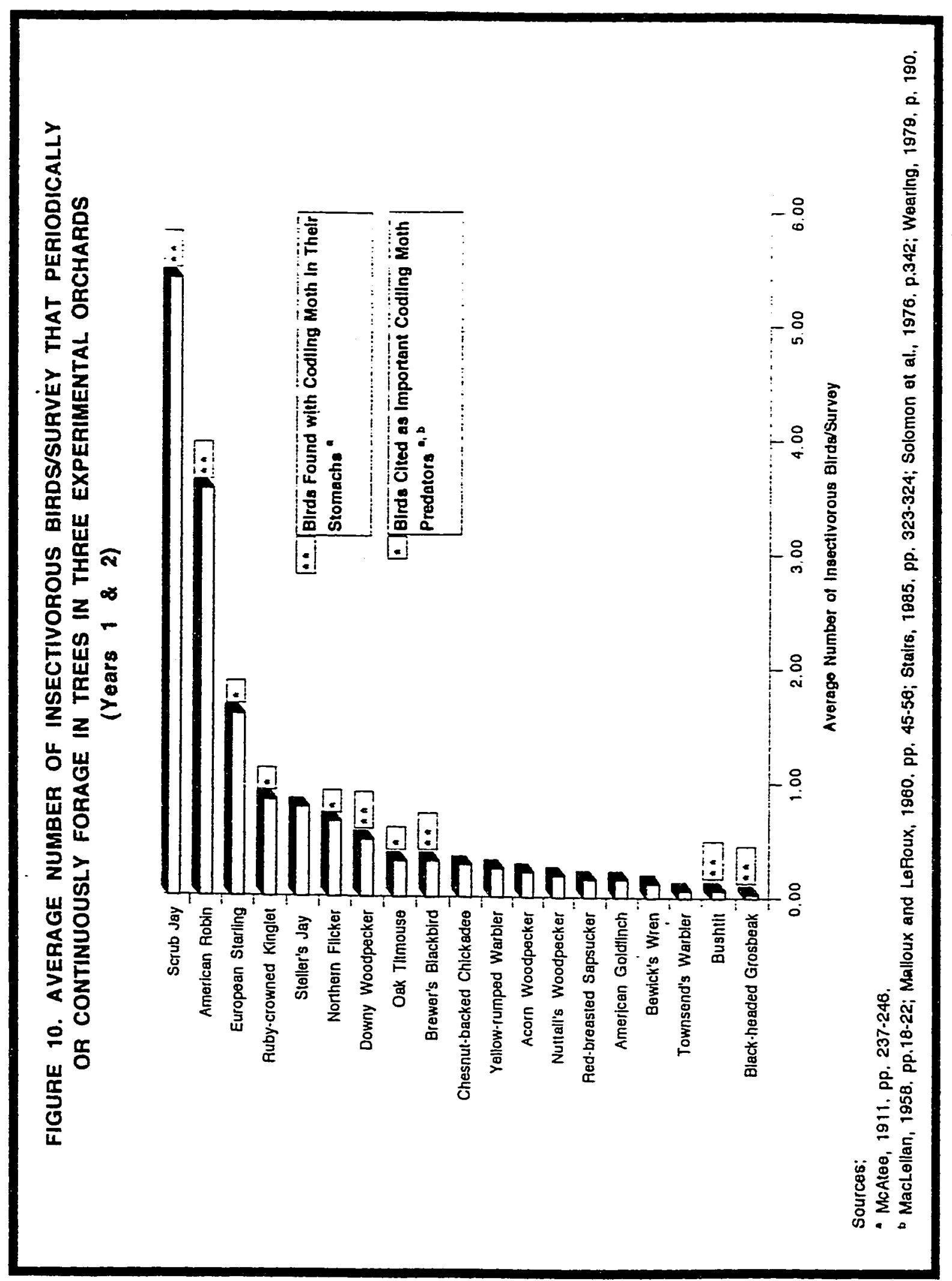




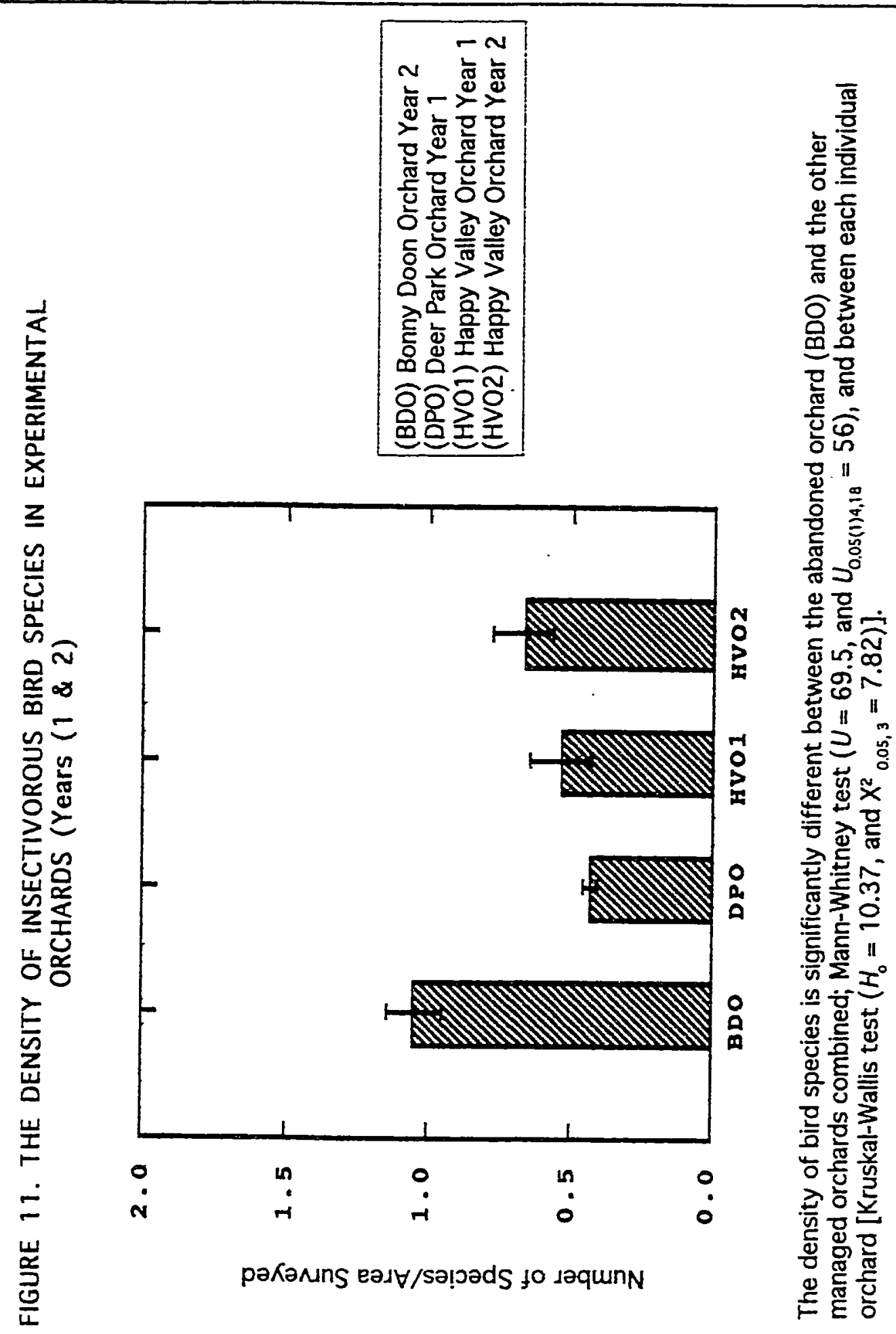




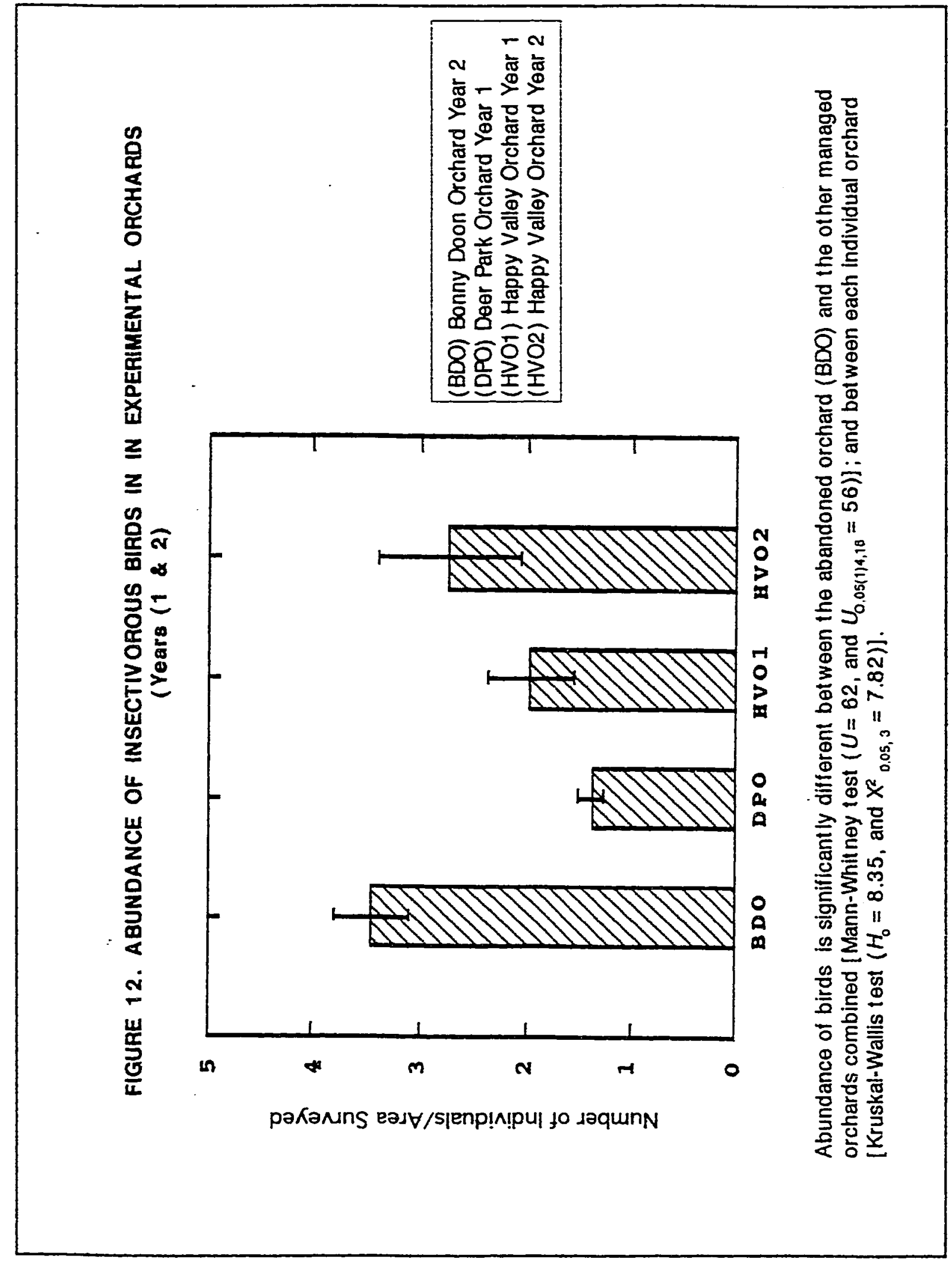




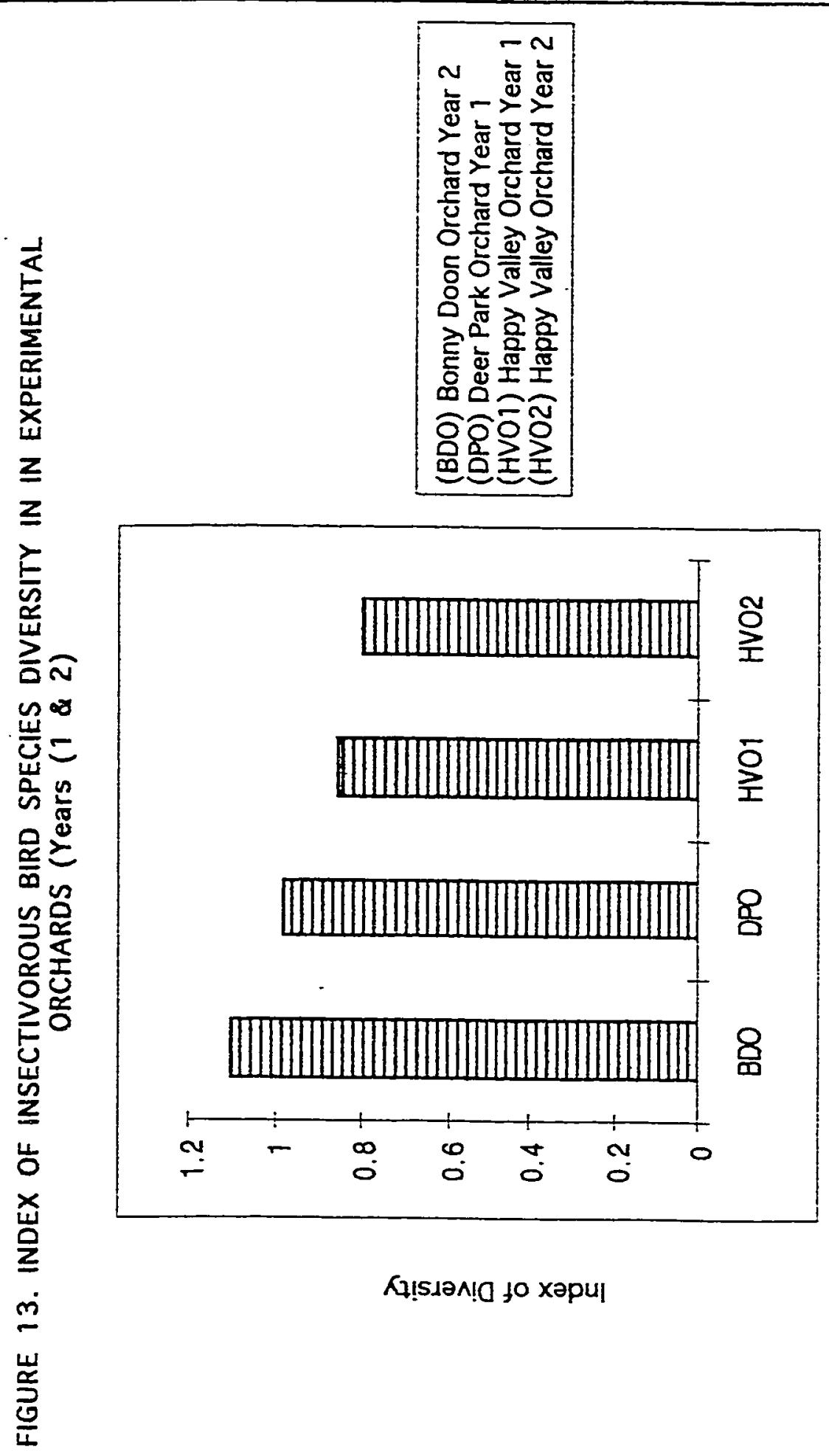

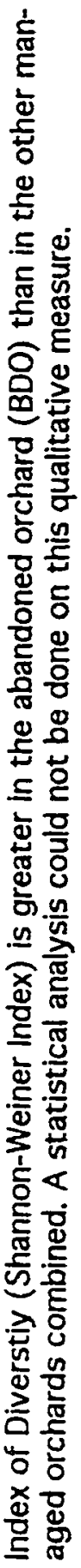




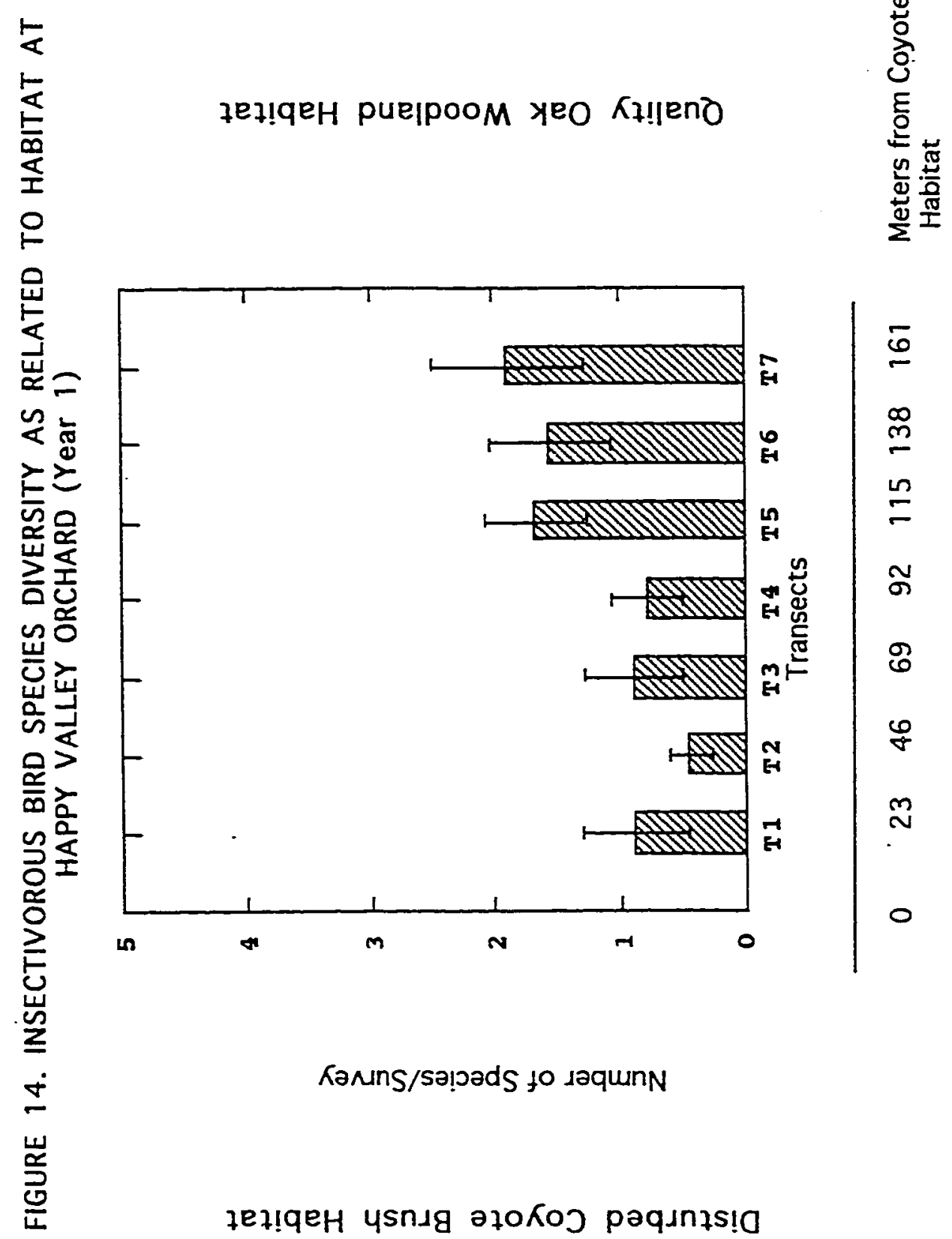




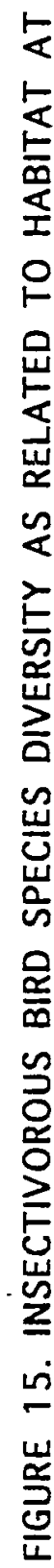

łez!qeH puejpoom yeO Ki!jenO

爱

定

赵

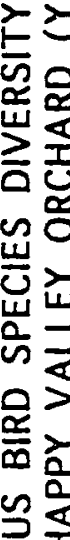

응

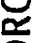

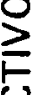

$\underline{\text { w }}$

เ่

KannS/Sa!jads to saqunN

峛
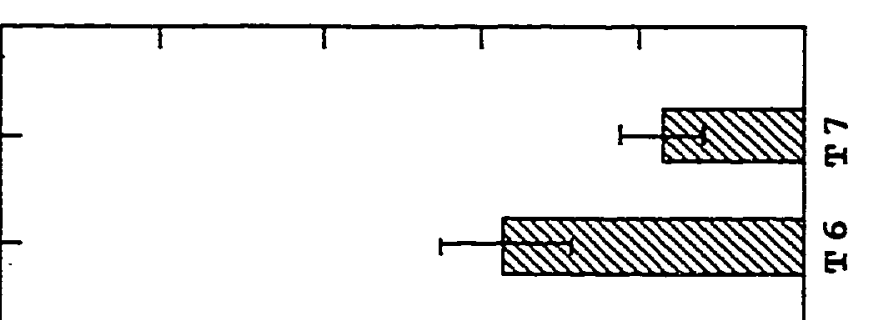

-

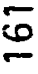

$\stackrel{\infty}{m}$

n

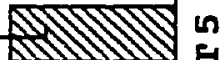

B
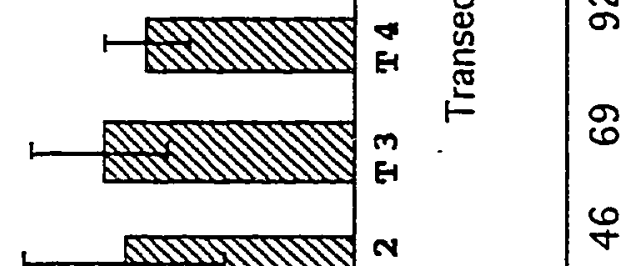

114

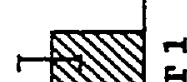

$\stackrel{m}{\sim}$

10
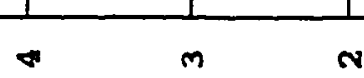

N

8

$\stackrel{8}{\forall}$

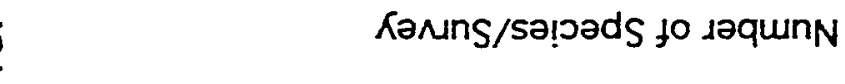

fez!qeH usnug әzokoว pәqunzs! 
䓀

它

䟚

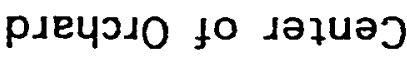

은

岂

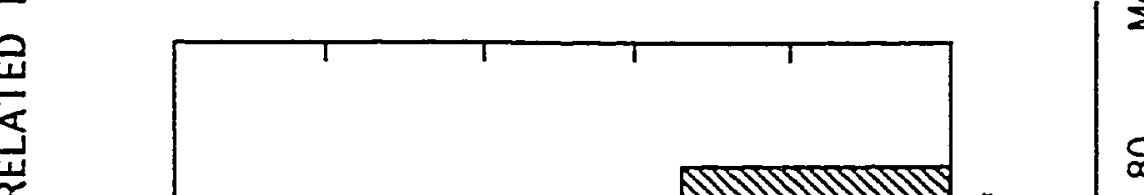

$<$

$>$ 柴

至

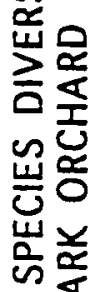

商

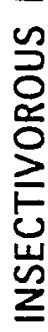

ம

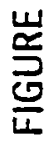

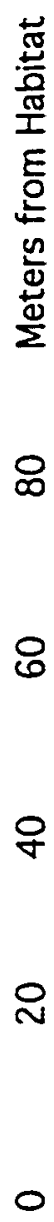

KannS/so!jads to jaqunN

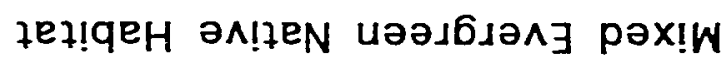


FIGURE 17. WOODPECKER FEEDING STRATEGY
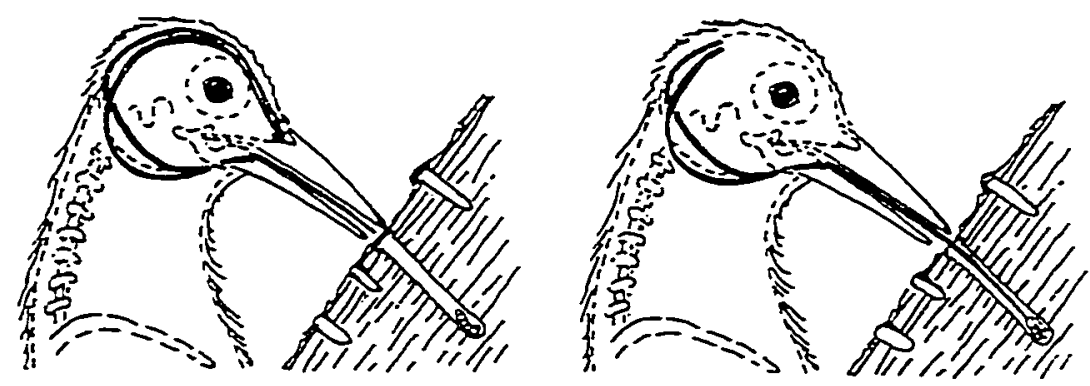

How exactly do Woodpeckers obtain their prey? After locating an insect, with its tongue retracted around the skull (left), a Woodpecker extends its tongue into a crevice (right). Its long tongue is coated with sticky saliva that helps to retain the prey. Although this bird is probably extracting a bark beetle or an ambrosia beetle and not a codling moth, the process is the same.

Source: Ehrlich, Dobkin, and Wheye, p. 353. 
APPENDIX 


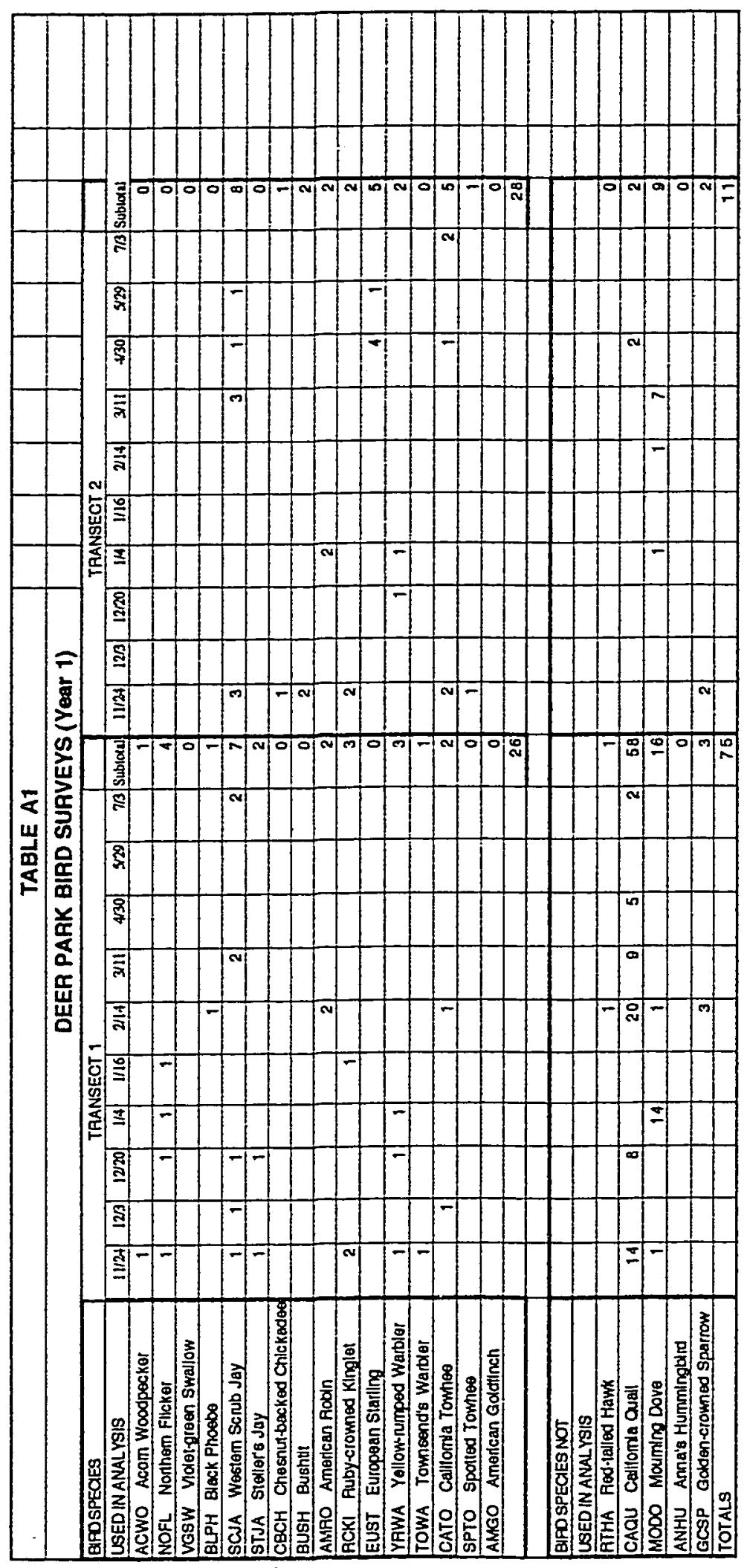




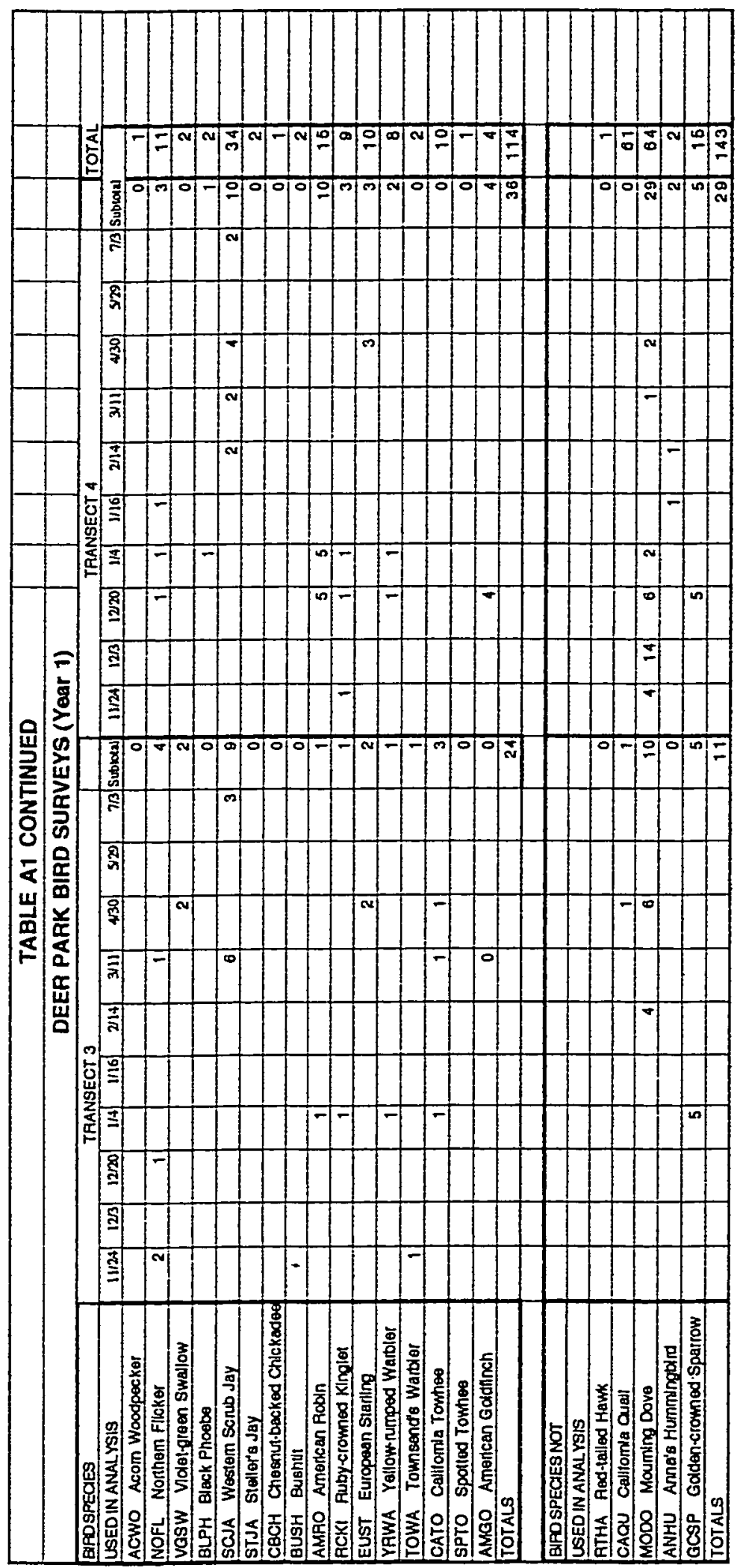




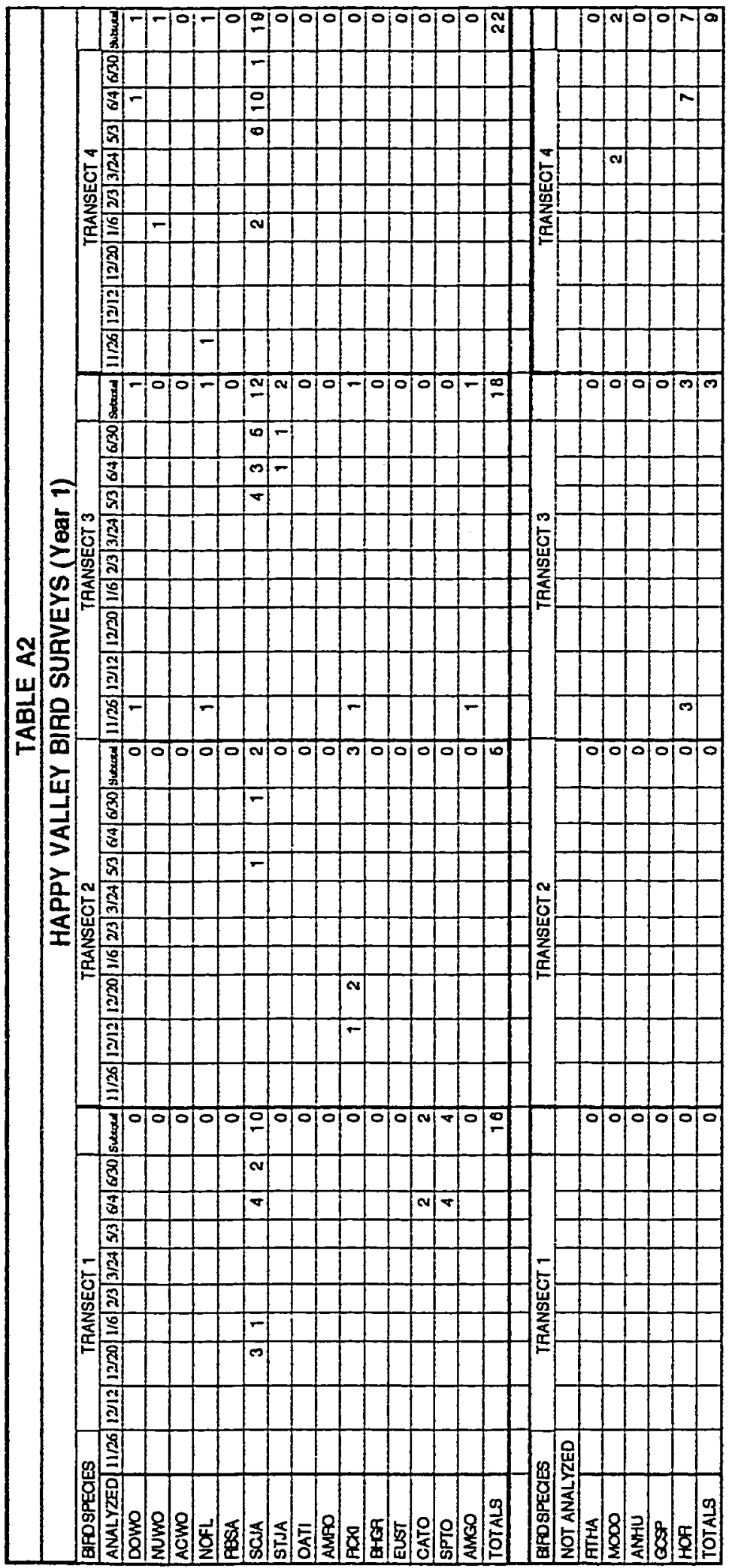




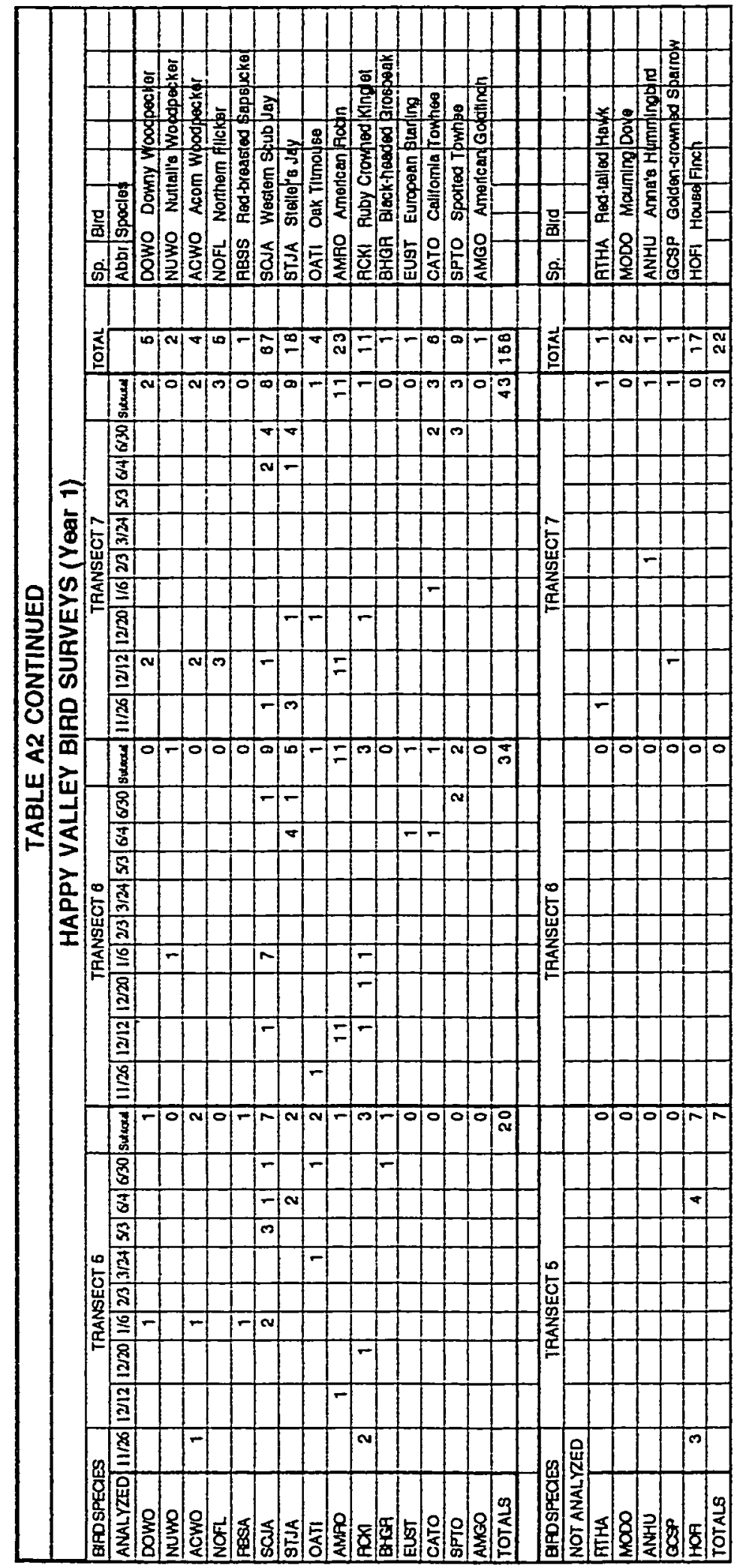




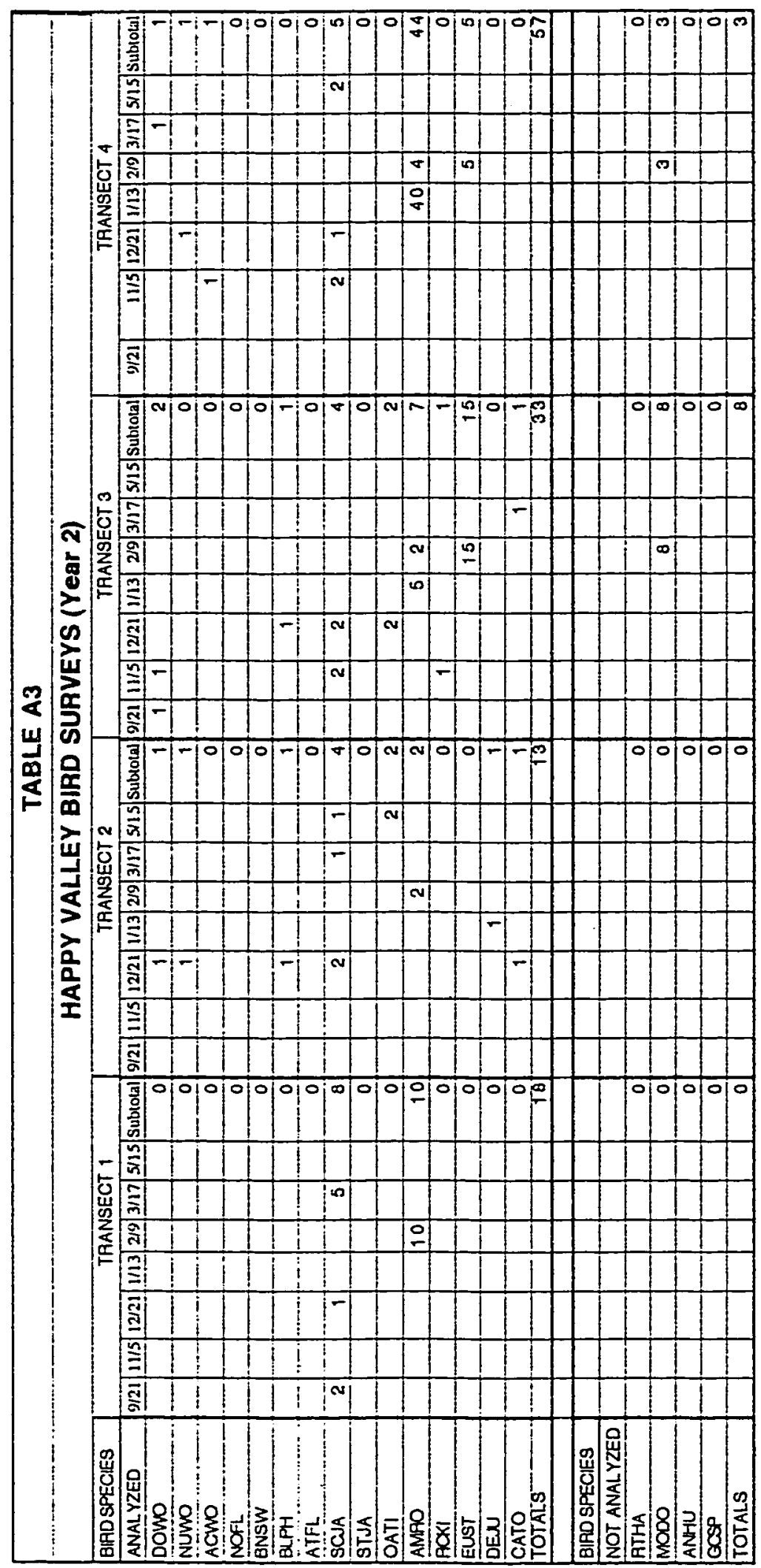




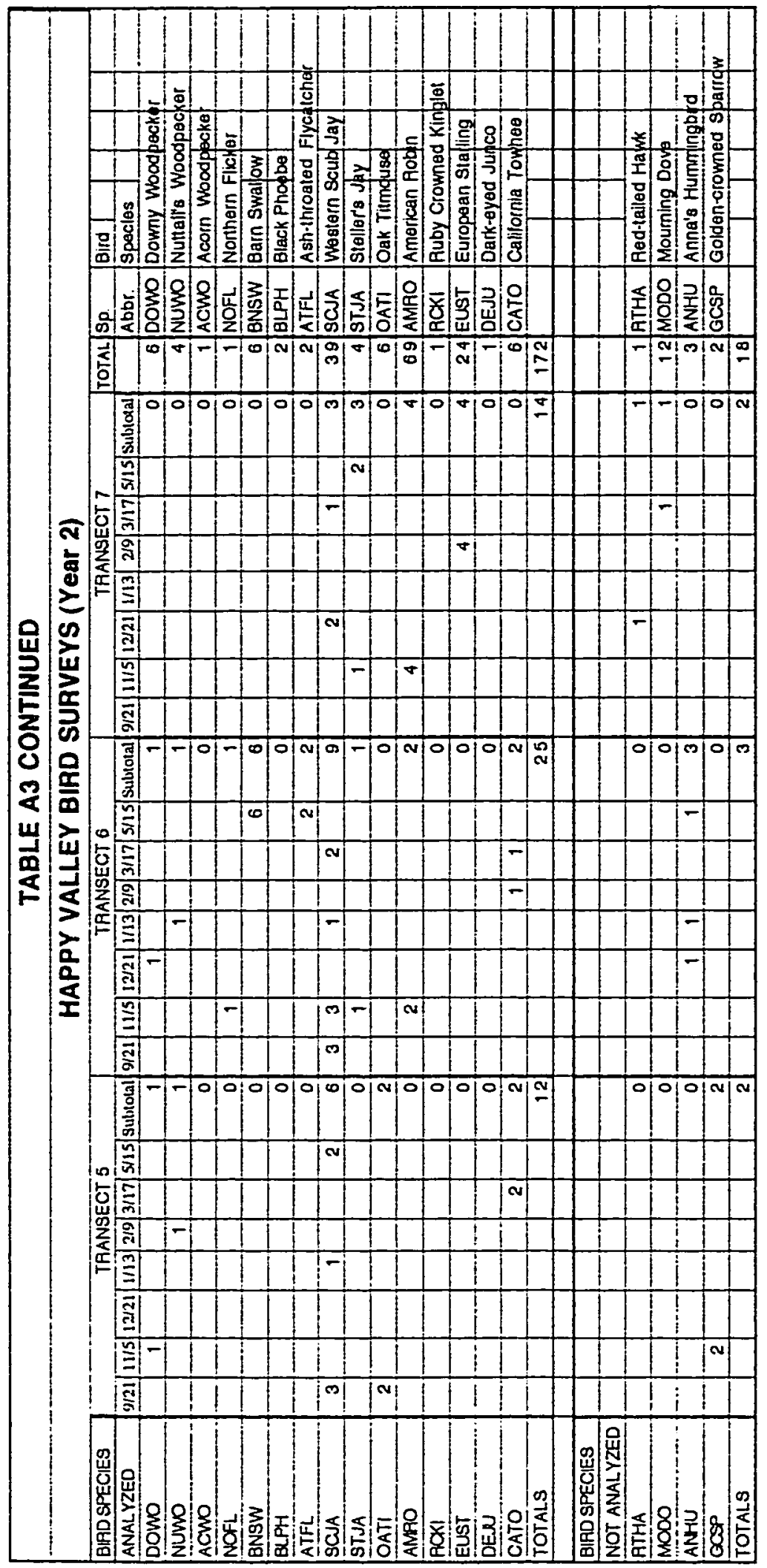




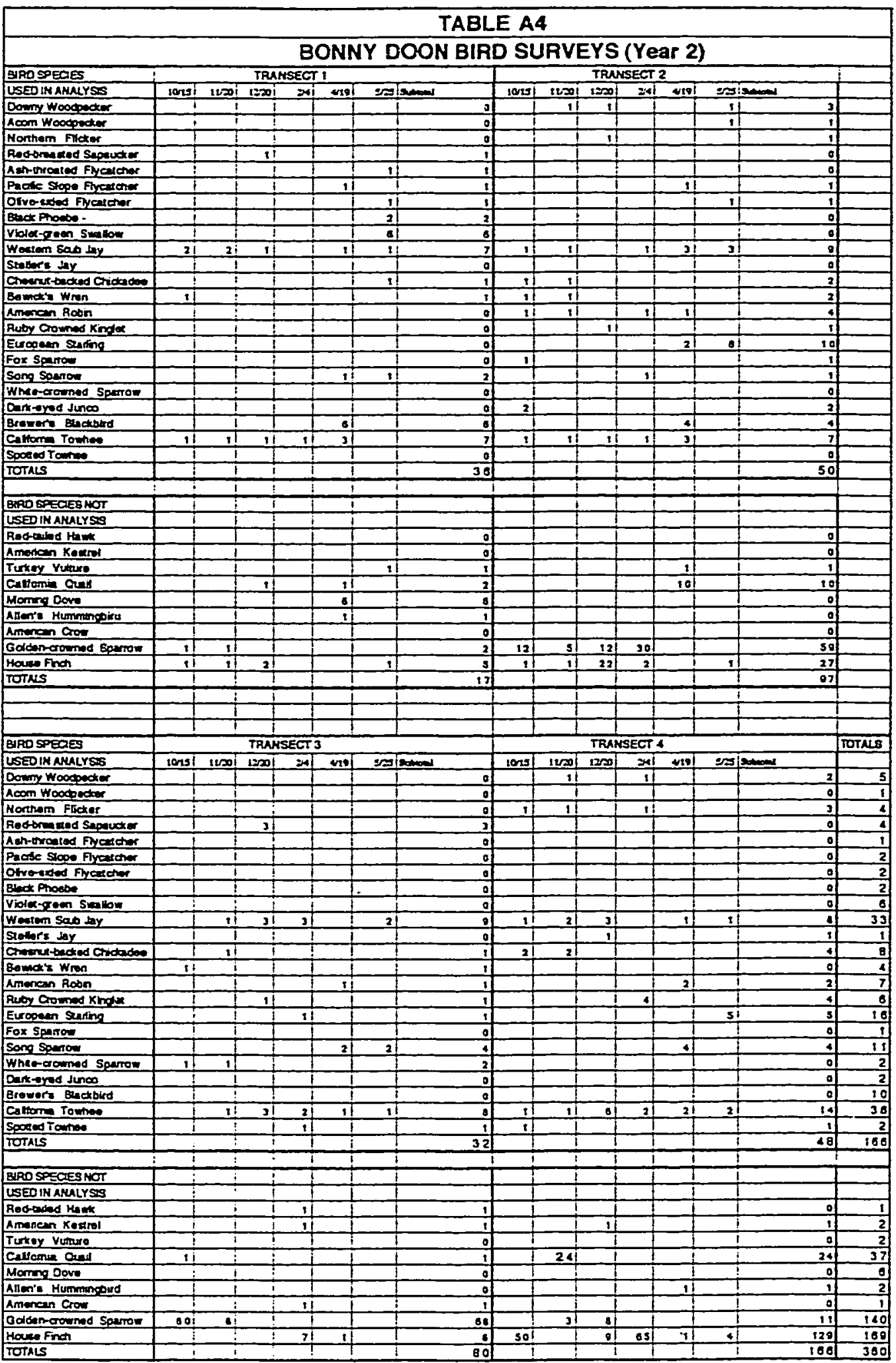




\section{LITERATURE CITED}

Altieri, M. A. and L. L. Schmidt. "Cover crops affect insect and spider populations in apple orchards." California Agriculture (February 1986): 15-17.

Atlegrim, $O$. "Exclusion of birds from bilberry stands: impact on insect larval density and damage to the bilberry." Decologia 79 (1989): 136-139.

Bakker, E. An island called California. Berkeley: University of California Press, 1972.

Barbour, M. G. and J. Major. eds. Terrestrial vegetation of California. New York: John Wiley \& Sons, 1977.

Benbrook, C. M. Pesticides at the crossroads. Yonkers: Consumers Union, 1996.

Besse, R. S. "Effect of agricultural and home economics research on Oregon's agricultural progress. A report of activities and accomplishments for biennium ending June 30, 1936." Oregon Agriculture Experiment Station Bull. 350 (1937).

Boyce, H. R. "Biological control of the codling moth in Ontario." Report of the Entomological Societv. Ontario no. 71 (1941): 40-44.

Brown, M. "Expanding options for codling moth control." The Cultivar (Summer, 1995): 5-7.

California Certified Organic Farmers (CCOF) Membership directory. Santa Cruz: CCOF, 1998.

Chakravarthy, A. K. "Bird predators of pod borers of field bean (Lablab niger Medick)." Tropical Pest Management 34 (1988): 395-398.

Cohen, B., R. Wiles and E. Bondoc. Weed Killers by the glass, A citizen's tap water monitoring project in 29 cities. Washington, D. C.: Environmental Working Group, 1995.

Consumer Price Index. Cost of Living Calculator. (1999, Sept. 21). [Online]. Available: http:/www.newsengin.com/neFREETOOLS.NSF/CPICALC.

Debach, P. and D. Rosen. Biological control by natural enemies. New York: Cambridge University Press, 1991.

Donley, M. W., Allan, S., Caro, P. and S. P. Patton. Atlas of California. Portland: Academic Book Center, 1979.

Ehrlich, P. R., D. S. Dobkin, and D. Wheye. The birder's handbook: A field guide to the natural history of North American birds. New York: Simon \& Schuster Inc., 1988

Falcon, L. A. and J. Huber. "Biological control of the codling moth." In Tortricid pests. their biology. natural enemies and control, vol. 5, ed. Helle, W., L. P. S. van deer Gest and H. H. Evenhuis, 355-369. Amsterdam: Elsevier, 1991. 
Ferreira, J. D. "A parasitic fungus on Cydia pomonella L." Revista Agronomica. Lisboa 31 (1943): 85-117.

Ferron, P. and J. J. Vincent. "Preliminary experiments on the use of Beauveria bassiana against Carpocapsa pomonella." Mitteilungen der Biologischen Bundesanstalt fur Land- und Fortwirtschaft (Berlin-Dahlem) vol. 180 (1978). Quoted in Falcon, L. A. and J. Huber. "Biological control of the codling moth." In Tortricid pests, their biology. natural enemies and control, vol. 5, ed. Helle, W., L. P. S. van deer Gest and H. H. Evenhuis, 355-369. Amsterdam: Elsevier, 1991.

Flint, M. L., ed. Integrated pest management for apples and pears. University of California Division of Agriculture and Natural Resources: Statewide integrated pest management project, 1991. Publication 3340.

Food and Drug Administration (FDA). 1992, 1993, 1994. Pesticide program residue monitoring.

Forbush, E. D. Useful birds and their protection. 3d ed. Boston: Massachusetts State Board of Agriculture, 1908.

. "The utility of birds." Massachusetts Department of Agriculture Bull. 9 (1921).

Geupel, G. R., and A. King. "Songbird response to biological prune systems protocol at Shasta View Farms: Progress report of the 1997 field season." Point Reves Bird Observatory (1998): 1-4.

Gill, F. B. Omithology. New York: W. H. Freeman and Co., 1989.

Gien, D. M. "Effects of natural enemies on a population of codling moth $C y d i a$ pomonella" Annals of Applied Biology 101 (1982): 199-201.

Glen, D. M. and N. F. Milsom. "Survival of mature larvae of codling moth (Cydia pomonella) on apple trees and ground." Annals of Applied Biology 90 (1978): 133146.

Glotfelty, D. E., J. N. Seiber, and L. A. Liljedahl. "Pesticides in fog." Nature 325 (1987): 602-625.

Gradwohl, J. and R. Greenberg. "The effect of a single species of avian predator on the arthropods of aerial leaf litter." Ecology. vol. 63, no. 2 (1982): 581-583.

Hagley, E. A. C. "The distribution and survival of overwintering codling moth larvae in southern Ontario." Proceedings of the Entomological Society of Ontario 100 (1969): $40-47$.

."The occurrence of fungal diseases of the codling moth in unsprayed apple orchards in Ontario." Proceedings of the Entomological Society of Ontario 101 (1971): 45-48. 
Hagley, E. A. C. and W. R. Allen. "Ground beetles (Coleoptera: Carabidae) as predators of the codling moth, Cydia pomonella (L.) (Lepidoptera: Tortricidae)." Canadian Entomologist 120 (1988): 917-925.

Holmes, R. T., J. C. Schultz, and P. Nothnagle. "Bird predation on forest insects: An exclosure experiment." Science 206 (1979): 462-463.

Jaques, R. P. and C. R. MacLellan. "Fungal mortality of overwintering larvae of the codling moth in apple orchards in Nova Scotia." Invertebrate Pathology 7 (1965): 291 296.

Jaynes, H. A., and P. E. Marucci. "Effect of artificial control practices on the parasites and predators of the codling moth." Journal of Economic Entomology 40 (1947): 9-25.

Knight, F. B. "The effects of woodpeckers on populations of the Engelmenn spruce beetle." Journal of Economic Entomology vol. 51, no. 5 (1958): 603-607.

MacLellan, C R. "Natural enemies of the light brown apple moth, Epiphyas postvittana, in the Australian Capital Territory." Canadian Entomologist 105 (1973): 68 1-700.

"Role of woodpeckers in control of the codling moth in Nova Scotia." Canadian Entomologist (Jan 1958): 18-22.

"Woodpeckers as predators of the codling moth in Nova Scotia." Canadian Entomologist no. 11 (Nov. 1959): 673-680.

"Woodpecker control of the codling moth in Nova Scotia orchards." Atlantic Naturalist vol. 16, no. 1 (1961): 17-21.

"Woodpecker ecology in the apple orchard." In Proceedings of the Tall Timbers Conference on ecological animal control by habitat management vol. 2, E. V. Komarek (Chariman), 273-284. 1971. Tallahassee: Tall Timbers Research Station.

Mailloux, M. and E. J. LeRoux. "Further observations on the life-history and habits of the codling moth, Carpocapsa pomonella (L.) (Lepidoptera: Tortricidae) in apple orchards of southwestern Quebec." Annual Report of the Quebec Pomological and Fruit Growing Society (1960): 45-56.

Marquis, R. J. "Insectivorous birds increase growth of white oak through consumption of leaf-chewing insects." Ecology vol. 75, no. 7 (1994): 2007-2014.

Martin, A. C., H. S. Zim, and A. L. Nelson. American wildlife and plants. A guide to wildlife food habits. New York: Dover Publications, 1951.

McAtee, W. L. "Bird enemies of the codling moth." In Yearbook of the United States Department of Agriculture, 1911, 237-246. Washington D. C.: Government Printing Office.

."Economic Ornithology." In Fifty years progress of American ornithology. American Omithologists' Union Memorial Volume, 1933. 
Pimentel, D. and A. Greiner. The pesticide question: environment, economics and ethics. New York: Routledge, Chapmen \& Hall, 1993.

Report of the Commissioner of Agriculture. Washington, D. C.: Government Printing Office, 1885.

Riddick, E. W. and N. J. Mills. "Potential of adult carabids (Coleoptera: Carabidae) as predators of fifth-instar codling moth (Lepidoptera: Tortricidae) in apple orchards in Califomia. Environmental Entomology (October 1994): 1338-1345.

Roesel von Rosenhof, A. J. "Insecten-Belustigen." Der Nachtvogel 4 te classe, no.13 (1746): 36. Quoted in McAtee, W. L. "Bird enemies of the codling moth." In Yearbook of the United States Department of Agriculture. 1911, 237-246. Washington D. C.: Government Printing Office.

Savary, A. and M. Baggiolini. "Contribution a L'etude de la lutte contre le carpocapse des pommes et des poires (Enarmonia pomonella L.)." Landwirtschaftliches Jahresbuch der Schweiz 69 (1955): 827-864.

Smith, J. N. M., and H. P. A. Sweatman. "Food-searching behavior of titmice in patchy environments." Ecology 55 (1974): 1216-1232.

Solomon M. E. and D. M. Glen. "Prey density and rates of predation by tits (Parus spp.) on larvae of codling moth (Cydia pomonella) under bark." Journal of Applied Ecology 16 (1979): 49-59.

Solomon M. E., D. M. Glen, D. A. Kendall and N. F. Milsom. "Predation of overwintering larvae of codling moth (Cydia pomonella (L.) by birds." Joumal of Applied Ecology 13 (1976): 341-352.

Stairs, G. R. "Predation on overwintering codling moth populations by birds." Ornis Scandinavica 16 (1985): 323-324.

Stiling, P. D. Introductory Ecology. Englewood Cliffs: Prentice-Hall, Inc, 1992.

Stockwn, W. "Codling moth resistance is concern to orchardists." California Farm Bureau's Ag Alert, 25 March 1998.

Thelander, C. ed. Life on the Edge. Berkeley: Heyday Books, 1994.

Thiem, H. and M. Sy. "On the importance of the destruction of Cydia pomonella by birds." Nachrichtenblatt der Deutschen Pflanzenschutzdienst 18 (1938): 95-97.

Wearing, C. H. "Integrated control of apple pests in New Zealand *3. Natural mortality of fifth-instar larvae of codling moth tagged with cobalt-58 in relation to their distribution." New Zealand Joumal of Zoology vol. 2, no. 1 (1975): 158-168.

. "Integrated control of apple pests in New Zealand * 10 . Population dynamics of codling moth in Nelson." New Zealand Joumal of Zoology 6 (1979): 165-199. 
Wearing, C. H., and L. Skilling. "Integrated control of apple pests in New Zealand *5. Effect of larval density on the cocooning behavior of fifth-instar codling moth larvae on young trees." New Zealand Journal of Zoology. vol. 2, no. 2 (1975): 257-263.

Wearing, C. H. and K. McCarthy. "Predation of codling moth Cydia pomonella L. by the Silvereye Zosterops lateralis (Latham)". Biocontrol Science and Technology 2 (1992): 285-295.

Wilson, B. W., M. J. Hooper, E. E. Littrell, P. J. Detrich, M. E. Hansen, D. P. Weisskopf, and J. N. Seiber. "Orchard dormant sprays and exposure of red-tailed hawks to organophosphates." Bulletin of Environmental Contam. Toxicol. 47 (1991): 717-724.

Zajac, R. "The influence of bird feeding on the number of overwintering larvae of codling moth, Laspeyresia pomonella (L.), in orchards of Central Poland." Ekologia Polska vol. 2, no. 4 (1979): 571-580.

Zalom, F. G., P. B. Goodell, L. T. Wilson, W. W. Barnett, and W. J. Bentley. DegreeDays: The calculation and use of heat units in pest management University of California Division of Agriculture and Natural Resources: Cooperative Extension, 1983. Leaflet 21373.

Zar, J. H. Biostatistical Analysis New York: Simon \& Schuster, 1996. 
